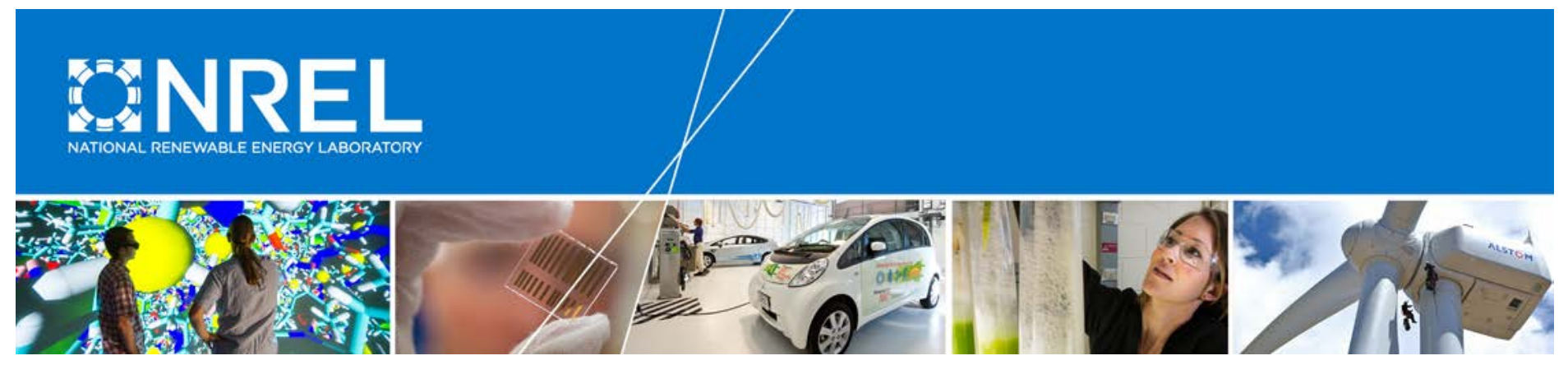

\title{
Charting the Emergence of Corporate Procurement of Utility-Scale PV
}

Jenny Heeter, Jeffrey J. Cook, and Lori Bird National Renewable Energy Laboratory

NREL is a national laboratory of the U.S. Department of Energy Office of Energy Efficiency \& Renewable Energy Operated by the Alliance for Sustainable Energy, LLC

This report is available at no cost from the National Renewable Energy Laboratory (NREL) at www.nrel.gov/publications.

Technical Report

NREL/TP-6A20-69080

September 2017 


\section{Charting the Emergence of Corporate Procurement of Utility-Scale PV}

Jenny Heeter, Jeffrey J. Cook, and Lori Bird National Renewable Energy Laboratory

Prepared under Task No. SETP.10306.20.01.30

NREL is a national laboratory of the U.S. Department of Energy Office of Energy Efficiency \& Renewable Energy Operated by the Alliance for Sustainable Energy, LLC

This report is available at no cost from the National Renewable Energy Laboratory (NREL) at www.nrel.gov/publications.

National Renewable Energy Laboratory 15013 Denver West Parkway Golden, CO 80401

303-275-3000 • www.nrel.gov

\section{Technical Report}

NREL/TP-6A20-69080

September 2017

Contract No. DE-AC36-08G028308 


\section{NOTICE}

This report was prepared as an account of work sponsored by an agency of the United States government. Neither the United States government nor any agency thereof, nor any of their employees, makes any warranty, express or implied, or assumes any legal liability or responsibility for the accuracy, completeness, or usefulness of any information, apparatus, product, or process disclosed, or represents that its use would not infringe privately owned rights. Reference herein to any specific commercial product, process, or service by trade name, trademark, manufacturer, or otherwise does not necessarily constitute or imply its endorsement, recommendation, or favoring by the United States government or any agency thereof. The views and opinions of authors expressed herein do not necessarily state or reflect those of the United States government or any agency thereof.

This report is available at no cost from the National Renewable Energy Laboratory (NREL) at www.nrel.gov/publications.

Available electronically at SciTech Connect http:/www.osti.gov/scitech

Available for a processing fee to U.S. Department of Energy and its contractors, in paper, from:

U.S. Department of Energy

Office of Scientific and Technical Information

P.O. Box 62

Oak Ridge, TN 37831-0062

OSTI http://www.osti.gov

Phone: 865.576.8401

Fax: 865.576.5728

Email: reports@osti.gov

Available for sale to the public, in paper, from:

U.S. Department of Commerce

National Technical Information Service

5301 Shawnee Road

Alexandria, VA 22312

NTIS http://www.ntis.gov

Phone: 800.553 .6847 or 703.605 .6000

Fax: 703.605.6900

Email: orders@ntis.gov 


\section{Acknowledgments}

This work was funded by the U.S. Department of Energy's (DOE's) Office of Energy Efficiency and Renewable Energy. The authors thank the Solar Energy Technologies Office for its support of this work.

For their thoughtful review of the document, the authors thank Daniel Boff (DOE), Stan Blackwell (Dominion Energy Virginia), Jack Sidler (New Mexico PRC), Tom MacLean and Heather Mulligan (Puget Sound Energy), Darren Kearney (South Dakota PUC), Joe Stagner (Stanford University), Priya Barua and Celina Bonugli (World Resources Institute), and Jaquelin Cochran and David Mooney of the National Renewable Energy Laboratory (NREL). We also thank Karin Haas for editorial support and Stacy Buchanan for graphics support.

We would like to thank the following individuals for participating in market interviews: Frederick Freeman (Apple), Gerry DaRosa (Arizona State University), Stan Blackwell (Dominion Energy Virginia), Stacy Phillips (Duke Energy Carolinas), Steve Kiesner (EEI), Bill Weihl (Facebook), Gary Demasi (Google), Joseph Roth (IKEA), Kevin Hagen (Iron Mountain), Seth Baruch (Kaiser Permanente), Cindy Ortega (MGM Resorts International), Vanessa Miler (Microsoft), Gaurav Shil (NV Energy), Heather Mulligan (Puget Sound Energy), Joe Stagner (Stanford University), and Steve W. Chriss (Walmart).

We are also appreciative of staff at state and federal organizations who provided information on corporate renewable procurement pathways in their jurisdictions: Patricia Smith (Alabama PSC), John Bethel (Arkansas PSC), Keith Hay (Colorado PUC), Debra Irwin and Gregory Basheda (Federal Energy Regulatory Commission), Cayce Hinton (Florida PUC), Jamie Barber (Georgia PSC), Venkata Bujimalla (Iowa Utilities Board), Randy Lobb (Idaho PUC), Dale Thomas (Indiana URC), Julie Baldwin (Michigan PSC), Michelle Rebholz (Minnesota PUC), Natelle Dietrich (Missouri PSC), Robin Arnold (Montana PUC), Sam Watson (North Carolina Utilities Commission), Sara Cardwell (North Dakota PUC), Scott Coburn (Nebraska PUC), Jack Sidler, Charlie Gunter, and Travis Blecha (New Mexico PRC), Doreen Harris (NYSERDA), Jason Chapin (Oklahoma Corporation Commission), Julie Peacock and Elaine Prouse (Oregon PUC), Darren Kearney (South Dakota PUC), William Powell (Utah PUC), Jeremy Twitchell (Washington UTC), Andrew Kell and Sam Shannon (Wisconsin PUC), Terry Eads (West Virginia PSC), and Marci Norby (Wyoming PUC).

\section{List of Acronyms}

$\begin{array}{ll}\text { ACORE } & \text { American Council on Renewable Energy } \\ \text { C\&I } & \text { Commercial and industrial } \\ \text { FERC } & \text { Federal Energy Regulatory Commission } \\ \text { PPA } & \text { Power purchase agreement } \\ \text { PSC } & \text { Alabama Public Service Commission } \\ \text { PUCN } & \text { State of Nevada Public Utilities Commission } \\ \text { REC } & \text { Renewable Energy Certificate }\end{array}$




\section{Executive Summary}

Corporations are procuring utility-scale photovoltaic (PV) generation to meet their renewable energy and financial goals for electricity. The corporate procurement of utility-scale PV has grown from less than 1\% of annual installed utility-scale capacity in 2014 to 9\% in 2016 (Shiao et al. 2017), and it accounted for 17\% in early 2017 (Honeyman et al. 2016). Through July 2017, corporate customers contracted for more than 2,300 MW of utility-scale solar, primarily using financial power purchase agreements (PPAs) and green tariff or bilateral contracts with utilities (43\% and 36\%, respectively) (Figure ES-1).

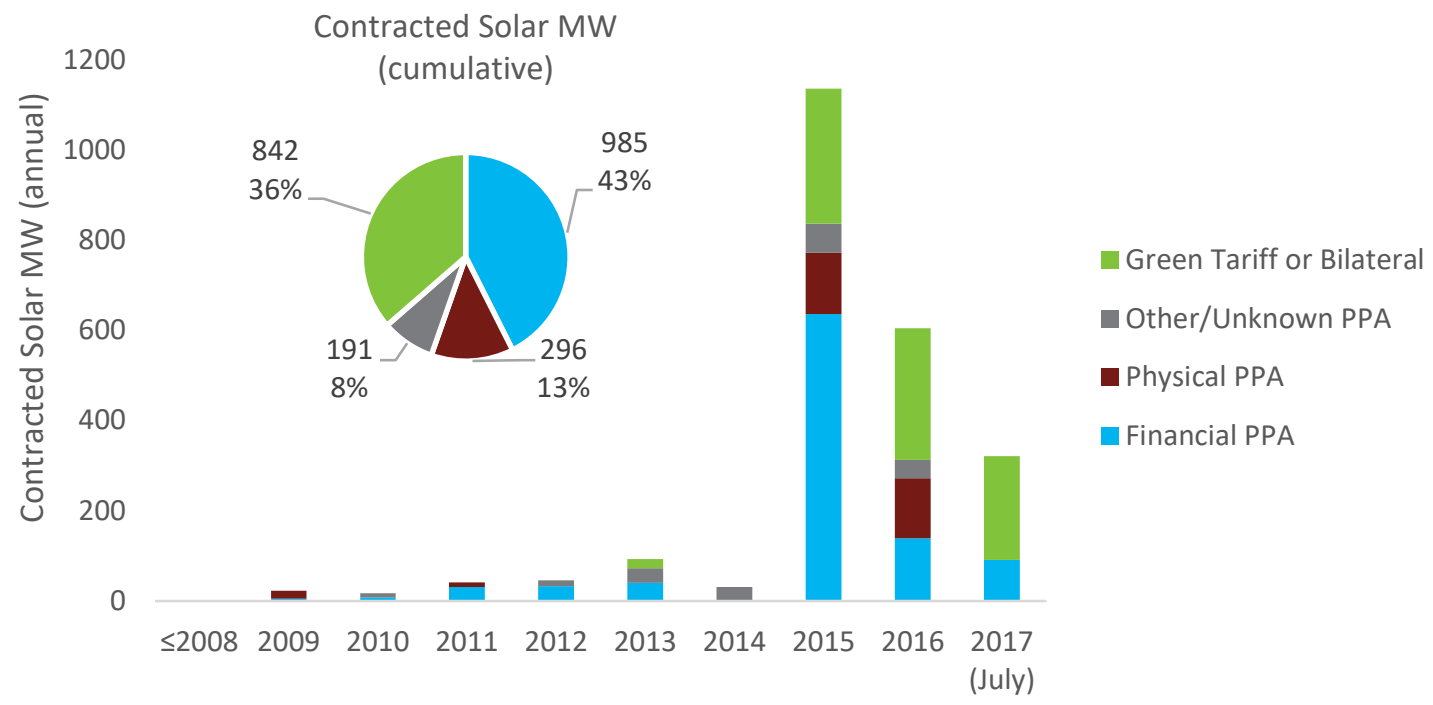

Figure ES-1. Corporate off-site solar contracts

Data from NREL and BNEF (2017)

Figure ES-1 includes PPAs and green tariff or bilateral contacts, which are in some cases enabled by retail choice and becoming a licensed wholesale seller of electricity. This paper examines the benefits, challenges, and outlooks for large-scale off-site solar purchasing through four pathways: PPAs, retail choice, utility partnerships (green tariffs and bilateral contracts with utilities), and by becoming a licensed wholesale seller of electricity. Each pathway differs based on where in the United States it is available, the value provided to a corporate off-taker, and the ease of implementation (Table ES-1). In addition, corporations will consider a range of metrics when determining which procurement option is most appropriate for them. 
Table ES-1. Comparison of Corporate Utility-Scale Procurement Models

\begin{tabular}{|c|c|c|c|c|}
\hline & $\begin{array}{l}\text { Power Purchase } \\
\text { Agreements }\end{array}$ & Retail Choice & $\begin{array}{l}\text { Utility } \\
\text { Partnerships }\end{array}$ & $\begin{array}{l}\text { Licensed } \\
\text { Wholesale } \\
\text { Electricity Seller }\end{array}$ \\
\hline Availability & $\begin{array}{l}\text { Typically requires } \\
\text { wholesale market } \\
\text { access }\end{array}$ & $\begin{array}{l}\text { Full or partial } \\
\text { access in } 21 \\
\text { states }\end{array}$ & $\begin{array}{l}\text { Certain utility } \\
\text { jurisdictions in } 17 \\
\text { states }\end{array}$ & $\begin{array}{l}\text { Any company that } \\
\text { owns or has } \\
\text { interest in owning } \\
\text { utility-scale } \\
\text { generation }\end{array}$ \\
\hline $\begin{array}{l}\text { Corporate } \\
\text { Access }\end{array}$ & $\begin{array}{l}\text { Large corporate } \\
\text { customers, and } \\
\text { emerging } \\
\text { aggregation } \\
\text { opportunities }\end{array}$ & $\begin{array}{l}\text { All or certain large } \\
\text { corporate } \\
\text { customers, no } \\
\text { aggregation } \\
\text { opportunities }\end{array}$ & $\begin{array}{l}\text { Certain large } \\
\text { corporate } \\
\text { customers and } \\
\text { emerging } \\
\text { aggregation } \\
\text { opportunities }\end{array}$ & $\begin{array}{l}\text { Any company, no } \\
\text { aggregation } \\
\text { opportunities }\end{array}$ \\
\hline $\begin{array}{l}\text { Energy Market } \\
\text { Expertise and } \\
\text { Corporate } \\
\text { Approval } \\
\text { Requirements }\end{array}$ & Medium-high & Medium-low & Low-low & Very high \\
\hline Contract Control & $\begin{array}{l}\text { Corporation } \\
\text { manages the } \\
\text { contract }\end{array}$ & $\begin{array}{l}\text { Corporation } \\
\text { manages the } \\
\text { contract }\end{array}$ & $\begin{array}{l}\text { Utility (in some } \\
\text { cases with input } \\
\text { from corporation) } \\
\text { manages the } \\
\text { contract }\end{array}$ & $\begin{array}{l}\text { Corporation } \\
\text { manages the } \\
\text { contract }\end{array}$ \\
\hline $\begin{array}{l}\text { Length of } \\
\text { Contract }\end{array}$ & 10-20 years & Negotiable & $\begin{array}{l}\text { Varies by utility } \\
\text { program }\end{array}$ & $\begin{array}{l}\text { Negotiable } \\
\text { (typically longer } \\
\text { term, 10-20 years) }\end{array}$ \\
\hline $\begin{array}{l}\text { Hedging } \\
\text { Opportunity and } \\
\text { Risk Profile }\end{array}$ & $\begin{array}{l}\text { High hedge value, } \\
\text { but subject to } \\
\text { wholesale market } \\
\text { hub or node price } \\
\text { volatility risk }\end{array}$ & $\begin{array}{l}\text { Hedge opportunity } \\
\text { depends on length } \\
\text { of contract and is } \\
\text { subject to retail } \\
\text { market price } \\
\text { volatility risk }\end{array}$ & $\begin{array}{l}\text { Hedge opportunity } \\
\text { depends on length } \\
\text { of contract, credit } \\
\text { structure, and/or } \\
\text { wholesale market } \\
\text { price volatility risk }\end{array}$ & $\begin{array}{l}\text { High hedge value, } \\
\text { but subject to } \\
\text { wholesale market } \\
\text { hub or node price } \\
\text { volatility risk }\end{array}$ \\
\hline $\begin{array}{l}\text { Reliability } \\
\text { requirements }\end{array}$ & $\begin{array}{l}\text { Utility delivers firm, } \\
\text { reliable power }\end{array}$ & $\begin{array}{l}\text { Supplier delivers } \\
\text { firm, reliable power }\end{array}$ & $\begin{array}{l}\text { Utility delivers firm, } \\
\text { reliable power }\end{array}$ & $\begin{array}{l}\text { Corporation might } \\
\text { need to establish } \\
\text { supplemental } \\
\text { contracts to secure } \\
\text { firm, reliable power }\end{array}$ \\
\hline Title to Power & Supplier & Supplier & Utility & Corporation \\
\hline
\end{tabular}


In order to expand corporate procurement of off-site solar, both a purchasing pathway and costcompetitive solar are required. Corporations typically are interested in purchasing least-cost renewables, with no preference of wind over solar, however, more wind has been contracted to date, largely due to its low-cost availability in Texas, along with the ability to sign a PPA. Figure ES-2 shows the levelized cost of energy (LCOE) of utility-scale solar using a one axis tracker, and corporate procurement of renewable energy, by resource and procurement pathway. To deploy more corporate off-site solar, new procurement pathways are needed, such as the green tariff that is enabling procurement of solar in Nevada.

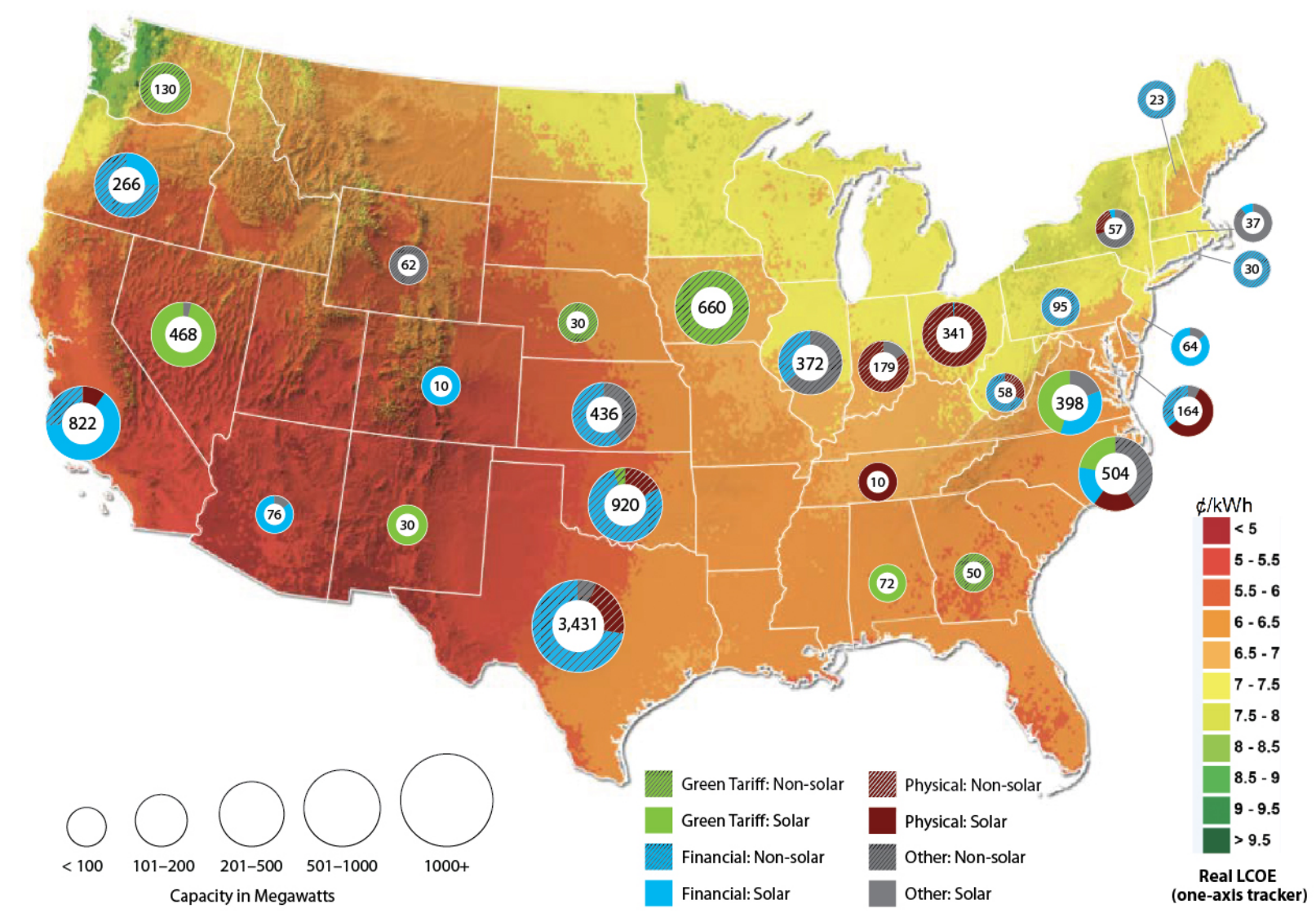

Figure ES-2. Corporate RE purchasing by state (MW) and utility-scale solar levelized cost of energy (LCOE)

LCOE source: Fu et al. (2016); capacity data from NREL and BNEF (2017)

Note: Non-solar technologies include wind and biomass

Of the states with the greatest solar potential (on an LCOE basis), California and Nevada have seen the greatest MW of corporate PV purchasing, through financial PPAs (California) and green tariffs (Nevada), but purchasing options are just emerging or do not exist in other areas of the country with strong solar potential. 


\section{Table of Contents}

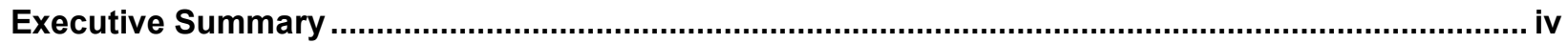

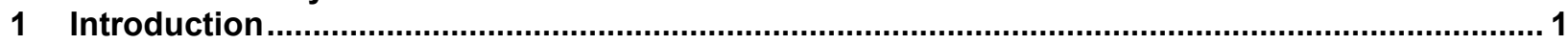

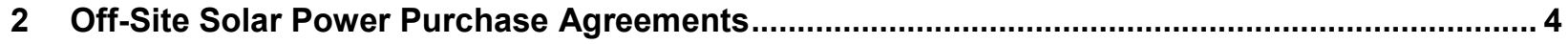

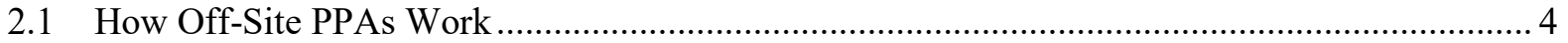

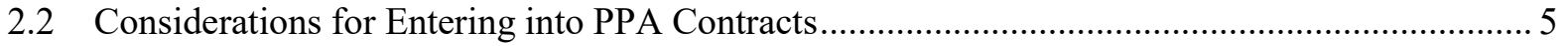

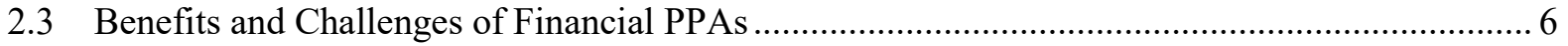

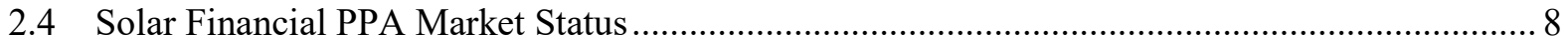

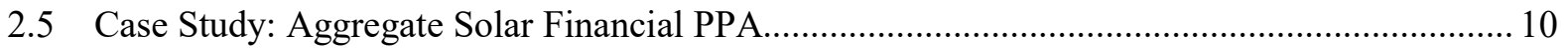

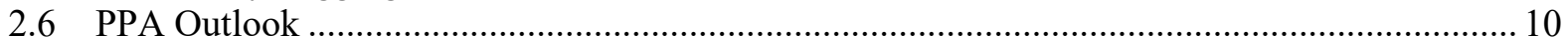

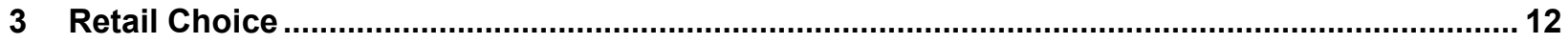

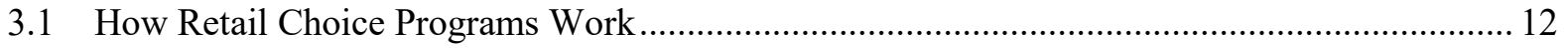

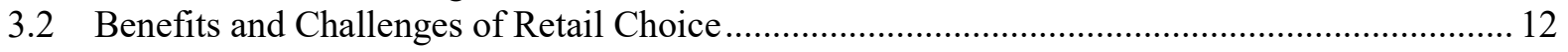

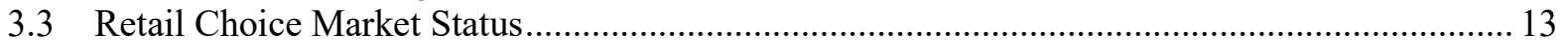

3.4 Case Study: MGM Exits Nevada Energy Territory for Wholesale Market ................................ 17

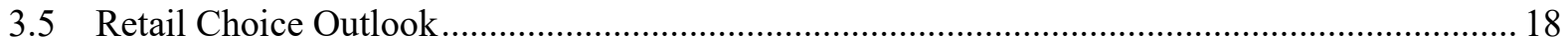

4 Utility Partnerships: Green Tariffs and Bilateral Contracts ............................................... 20

4.1 How Utility Partnerships Work ....................................................................................... 20

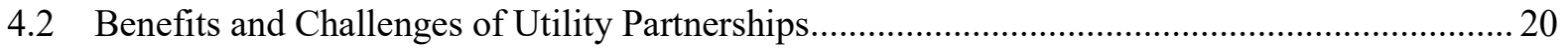

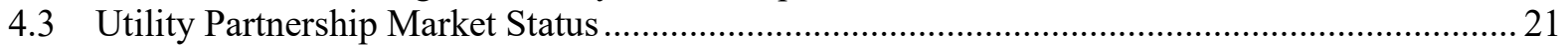

4.4 Case Study: Alabama Power Renewable Procurement Program ............................................. 25

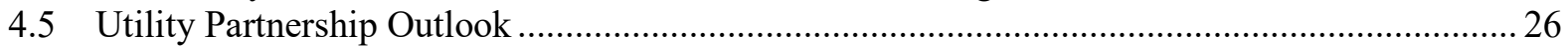

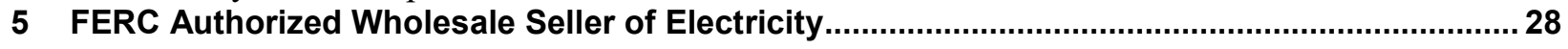

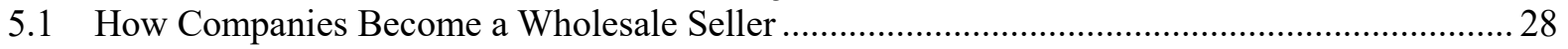

5.2 Benefits and Challenges of Wholesale Market Participation .................................................. 29

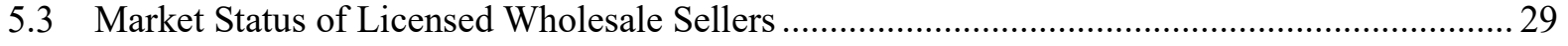

5.4 Case Study: Google Energy's Market-Based Rate Authority .................................................. 30

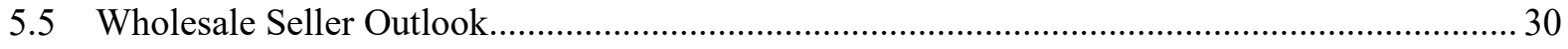

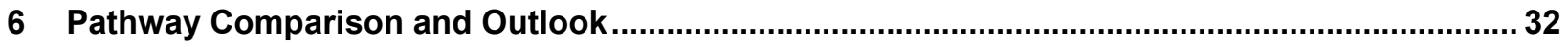

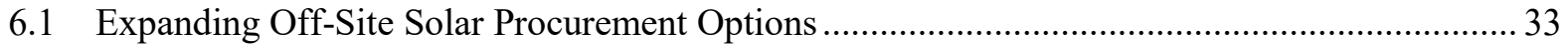

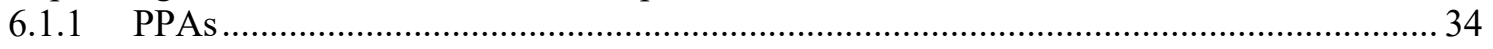

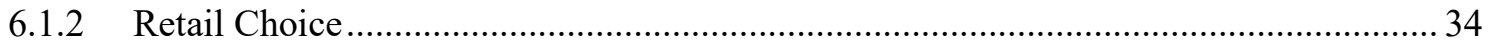

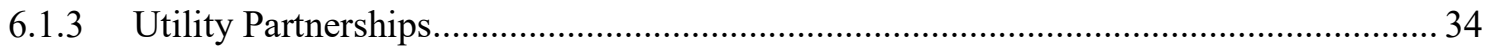

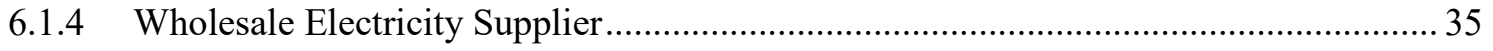

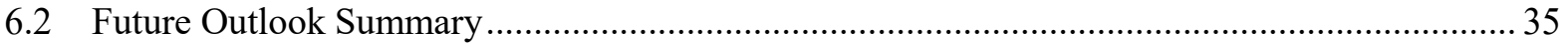

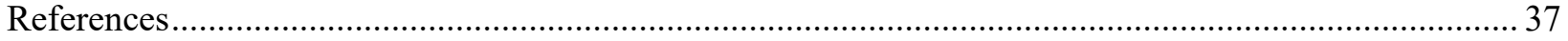




\section{List of Figures}

Figure ES-1. Corporate off-site solar contracts iv

Figure ES-2. Corporate RE purchasing by state (MW) and utility-scale solar levelized cost of energy (LCOE).

Figure 1. Corporate off-site solar contracts 2

Figure 2. Common cash and Renewable Energy Certificate (REC) flow under a financial PPA................ 4

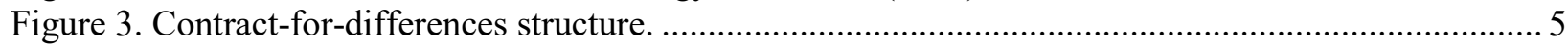

Figure 4. Map of regional transmission organizations and independent system operators........................ 6

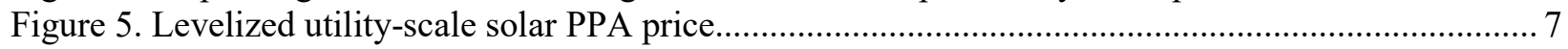

Figure 6. Corporate off-site PPAs (any technology) by contract type and signing year............................ 9

Figure 7. Corporate off-site solar PPAs by contract type and signing year .............................................. 9

Figure 8. Retail choice options for commercial and industrial customers ........................................... 13

Figure 9. Percentage of 2015 retail sales sourced from retail service providers in restructured markets... 14

Figure 10. Percentage of 2015 retail sales sourced from retail service providers in partial retail choice

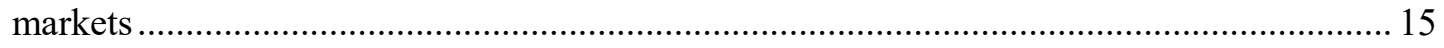

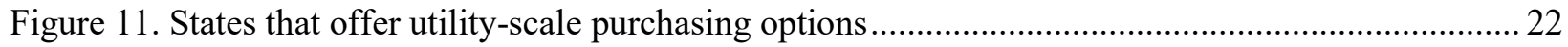

Figure 12. Corporate renewable energy contracts with regulated utilities by year...................................2 24

Figure 13. Corporate RE purchasing (MW) by state and utility-scale solar levelized cost of energy

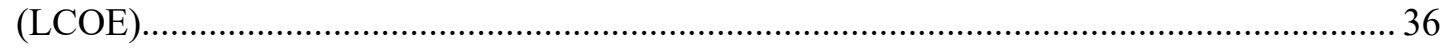

\section{List of Tables}

Table ES-1. Comparison of Corporate Utility-Scale Procurement Models .............................................. v

Table 1. Concentration of Financial PPAs (any technology type) by Region, though July 2017............... 7

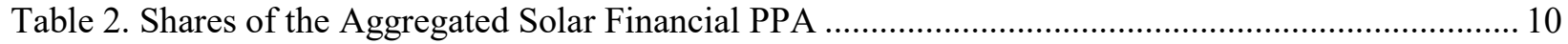

Table 3. Comparison of Partial Retail Choice Programs by State …….................................................. 15

Table 4. Comparison of Selected Approved Utility Green Tariff Programs ............................................ 23

Table 5. Bilateral Agreements for Renewable Energy by State, Company, and Utility .......................... 25

Table 6. Comparison of Corporate Utility-Scale Procurement Models ...................................................... 33 


\section{Introduction}

Historically, the utility-scale solar market has been driven by utility purchases used to meet state renewable portfolio standards (Honeyman et al. 2016). More recently, corporations and other nonresidential customers have shown interest in voluntarily purchasing utility-scale solar, which has driven growth in this market segment (O'Shaughnessy, Liu, and Heeter 2016; Honeyman et al. 2016). ${ }^{1}$ Corporations, in particular, are purchasing solar to achieve their own objectives, such as meeting sustainability goals, generating attractive returns on investment, and limiting exposure to energy price variability ( $\mathrm{PwC} 2016$; American Council on Renewable Energy [ACORE] 2016; Edwards et al. 2016).

To meet these objectives, corporations have leveraged on-site pathways such as installing rooftop systems to serve a portion of on-site demand (Honeyman et al. 2016). Large retail, distribution, manufacturing, and data centers have led this sector, accounting for $88 \%$ of installed capacity (Litvak 2016). These facilities often have large footprints and significant rooftop space for solar installations. However, not all corporations can leverage on-site opportunities. For example, some lack sufficient or suitable rooftop space or do not own their facilities. In addition, often on-site generation can meet only a relatively small fraction of a corporation's electricity load, which means that corporates may need to seek off-site procurement options to meet a greater fraction of their load with renewables.

Given these constraints to on-site installations, off-site procurement can be an attractive approach to achieving renewable energy objectives. To procure solar from facilities located offsite, corporations can work with their utility and individual project developers or buy renewable generation on the wholesale market. These approaches enable corporations to purchase solar from utility-scale generators, typically at competitive prices (National Renewable Energy Laboratory 2016). Corporations can also sign fixed, long-term energy contracts that offer price certainty for 10-20 years to help them achieve their sustainability goals while potentially reducing long-term energy costs (ACORE 2016).

Off-site solar procurement has become increasingly attractive as non-utility procurement of utility-scale solar has grown from less than $1 \%$ of annual installed utility-scale capacity in 2014 to $9 \%$ in 2016 (Shiao et al. 2017), and 17\% in early 2017 (Honeyman et al. 2016). Through July 2017, corporate customers contracted for more than 2,300 MW of utility-scale solar (Figure 1).

\footnotetext{
${ }^{1}$ In this report, we use the term "corporate" to refer to non-utility off-takers, which includes government off-takers.
} 


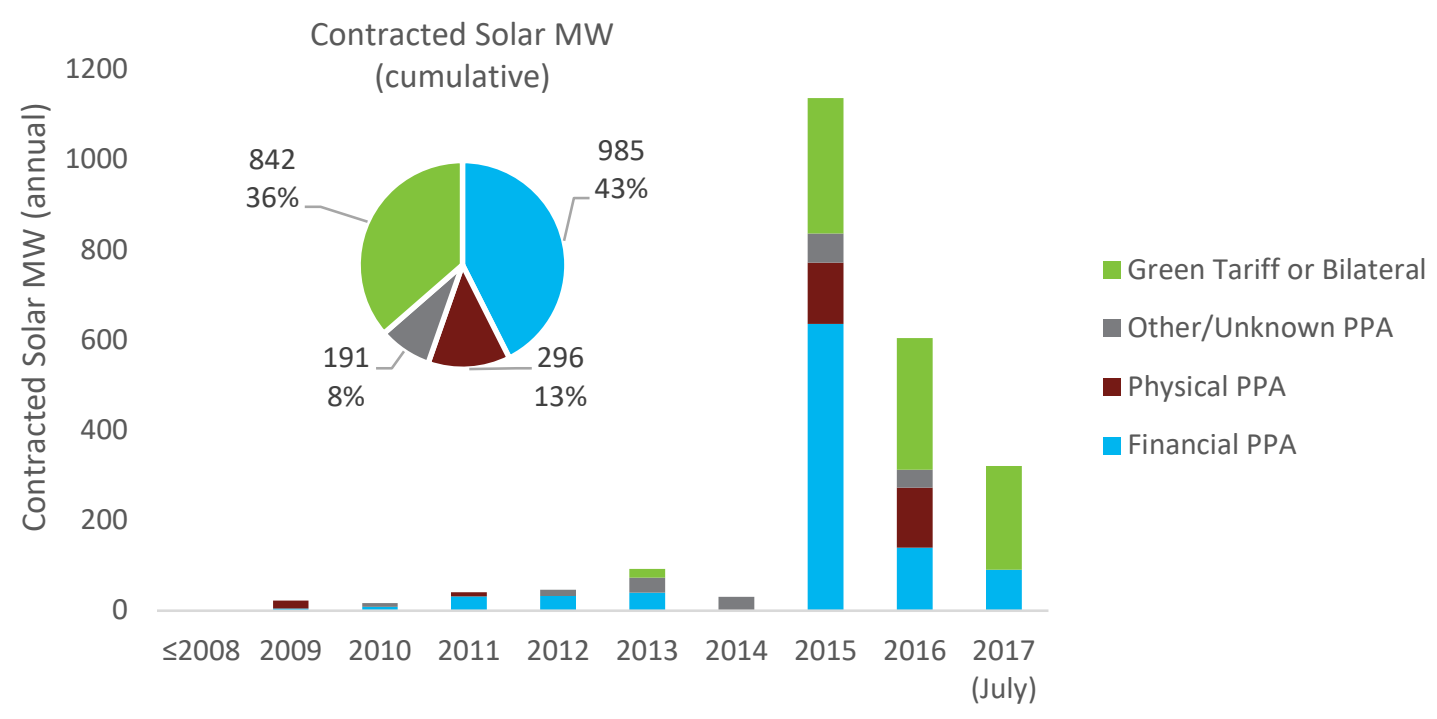

Figure 1. Corporate off-site solar contracts

Data from NREL and BNEF (2017)

Figure 1 includes PPAs and green tariff or bilateral contacts, which are in some cases enabled by retail choice and becoming a licensed wholesale seller of electricity. Given the increase in corporate purchases of off-site utility-scale solar generation, the goal of this report is to compare and assess four of the more common approaches corporations have used to purchase off-site solar generation, including:

- Power purchase agreements (PPAs): Through the use of a PPA, a corporate customer can sign a long-term contract with a developer to secure physical or financial rights to electricity generation and the environmental attributes of a project. ${ }^{2}$

- Retail choice: In states that allow retail choice, a corporate customer has the opportunity to purchase electricity from a competitive supplier on a short-term or long-term basis.

- Utility partnerships: Some utility service territories offer green tariff options that allow a corporate customer to enter into an agreement with their utility to procure renewable energy from a utility-owned or managed project with an established long-term rate; other utilities have established bilateral contracts that allow similar structures but for only one customer.

- Licensed wholesale electricity seller: A corporation can seek authority from the Federal Energy Regulatory Commission (FERC) to buy and sell electricity on the wholesale market.

\footnotetext{
${ }^{2}$ Throughout this report, we present data on contracts for solar, however, in many cases the treatment of the associated renewable energy certificates (RECs) has not been disclosed. In some cases, corporates sign a PPA with a solar generator, sell the solar RECs from the project, and buy RECs from another facility to ensure they can make a renewable energy claim in their marketing materials and greenhouse gas accounting.
} 
To provide a more complete understanding of how these models have been used in practice and their associated challenges, we conducted interviews with more than 40 public utilities commission staff, corporations, and utilities from across the United States.

This report discusses details of the four pathways, including how they are used in practice, where they are available, their overall market penetration, and the benefits and challenges associated with implementation. The report then compares the pathways across a range of metrics that can be used by corporations in evaluating procurement options, including access, hedging opportunities, contract requirements, and implementation challenges. The report concludes with insights from interviewees regarding strategies to expand corporate access to these pathways and reduce implementation costs. 


\section{Off-Site Solar Power Purchase Agreements}

This section explores how PPA contracts work, considerations for entering into PPAs, and the benefits to corporates. It focuses on financial PPAs in particular, including the benefits and challenges of entering into financial PPA contracts, recent market activity and procurement of financial PPAs, and finally the outlook for PPA procurement in coming years.

\subsection{How Off-Site PPAs Work}

Off-site solar PPAs, which can be either physical or financial in structure, have been on the rise. Physical PPAs are contracts wherein the electricity is contractually delivered to the buyer. Under physical PPAs, the solar generation is contracted on a long-term basis by the corporate purchaser and delivered by an energy supplier. Financial PPAs, also called "virtual" PPAs, are contracts in which a consumer agrees to purchase power but does not have the electricity delivered; instead the electricity is resold into a wholesale market (Figure 2). The consumer continues to purchase electricity from their utility. These contracts represent the majority of off-site renewable energy contracts signed by non-utilities in recent years.

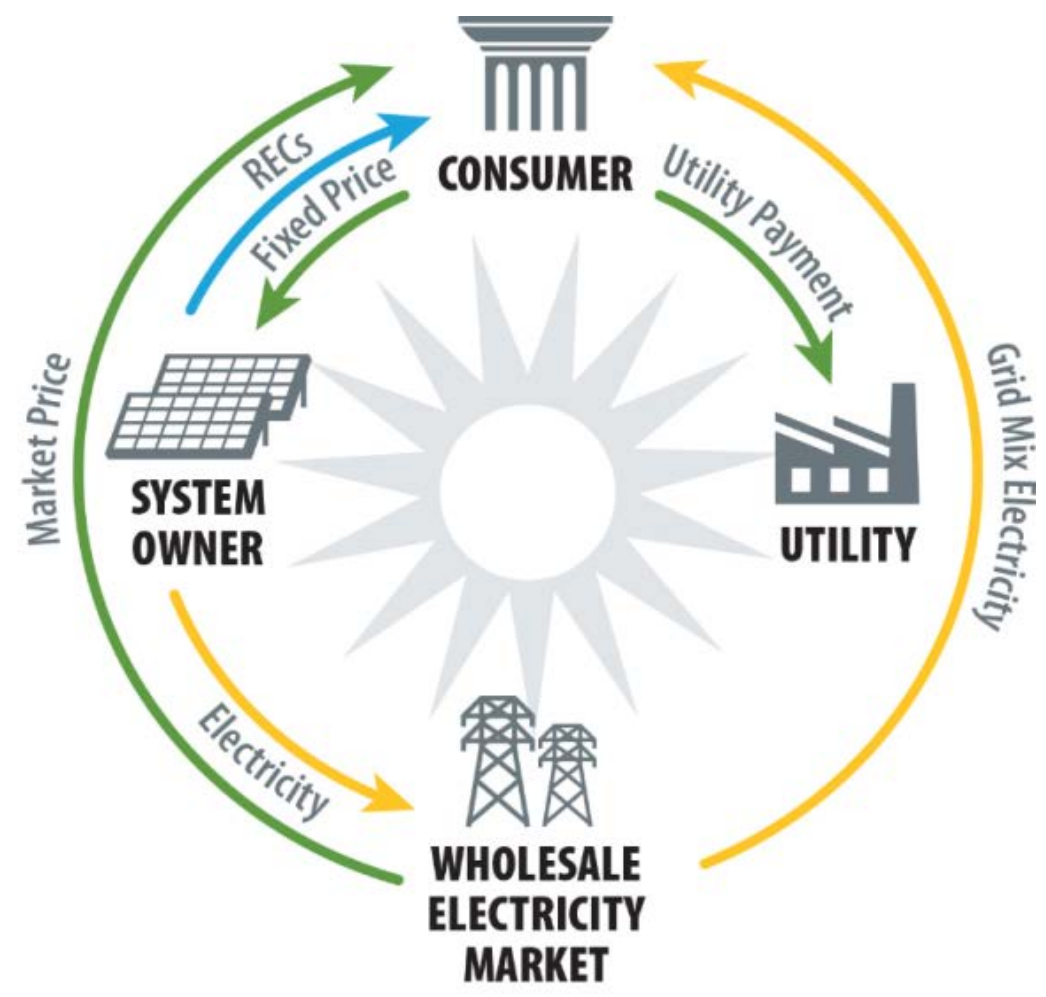

Figure 2. Common cash and Renewable Energy Certificate (REC) flow under a financial PPA.

Note: RECs might flow to the consumer; many times they are sold to other parties.

Agreements are typically structured as a contract for differences, a derivative product that does not involve physical or contractual delivery of electricity. Under a contract for differences, the consumer agrees to pay a fixed price to the developer. If the energy sold into the wholesale market receives more than the fixed price, the developer pays the off-taker the difference and vice versa (Figure 3). 


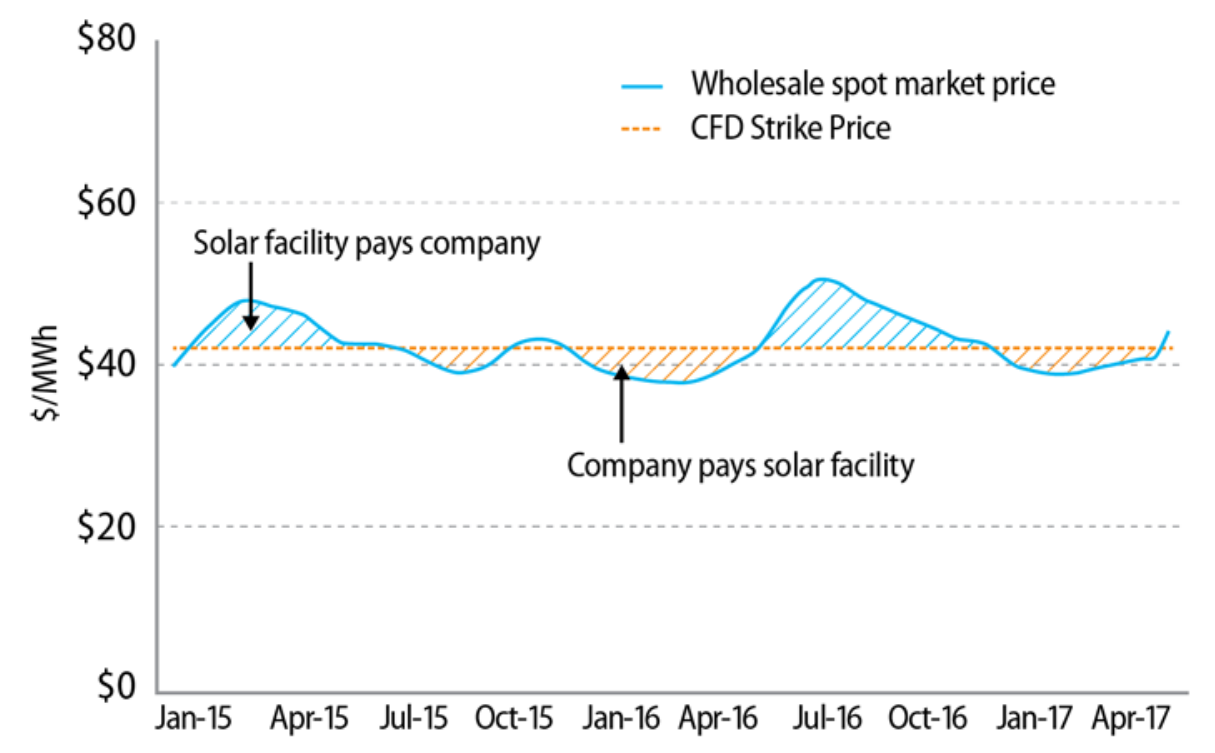

Figure 3. Contract-for-differences structure.

Illustration adapted from Catasein (2015)

\subsection{Considerations for Entering into PPA Contracts}

Before signing a PPA, corporations need to understand their electricity use (e.g., how much, in what locations) and frame their renewable energy goals. Then corporations might choose to work with a consultant or work in-house to develop a solicitation for renewable energy projects. After the solicitation is issued, the corporation can begin negotiation.

The negotiation process can be time-consuming, particularly if corporate senior executives are unfamiliar with financial PPAs. Interviewees noted that the time to sign a financial PPA is reduced after the first one is completed, but the process can be difficult depending on the energy and finance experience of senior management. In negotiations, parties will determine the point at which the price is settled - either at the bus bar market price or the hub market price. In some cases, the difference between the bus bar market price and the hub market price can be significant (for example, if there is transmission congestion) (Renewable Choice Energy 2016). Thus, corporations might seek to settle projects at the hub price and have the renewable project owner manage the basis risk. Other terms to negotiate include the duration of the contract, REC ownership, and performance guarantees (DLA Piper 2016).

Among all options to purchase off-site renewable energy, during our interviews many corporations noted that they preferred signing financial PPAs but are hindered by the inability to use this mechanism in many states and regions where they operate. Using a financial PPA requires that the generator be located in an area that has a regional transmission organization/independent system operator (Figure 4). In addition, the hedge value is related to how closely the corporation's retail rates track wholesale rates. Having locational proximity can minimize the risk that the wholesale price earned by the renewable generator tracks the rates the corporate customer will continue to pay to their existing electricity supplier. Therefore, to make the financial PPA as highly correlated with the corporate customer's load as possible, corporate customers seek renewable projects located close to their large electricity loads. 


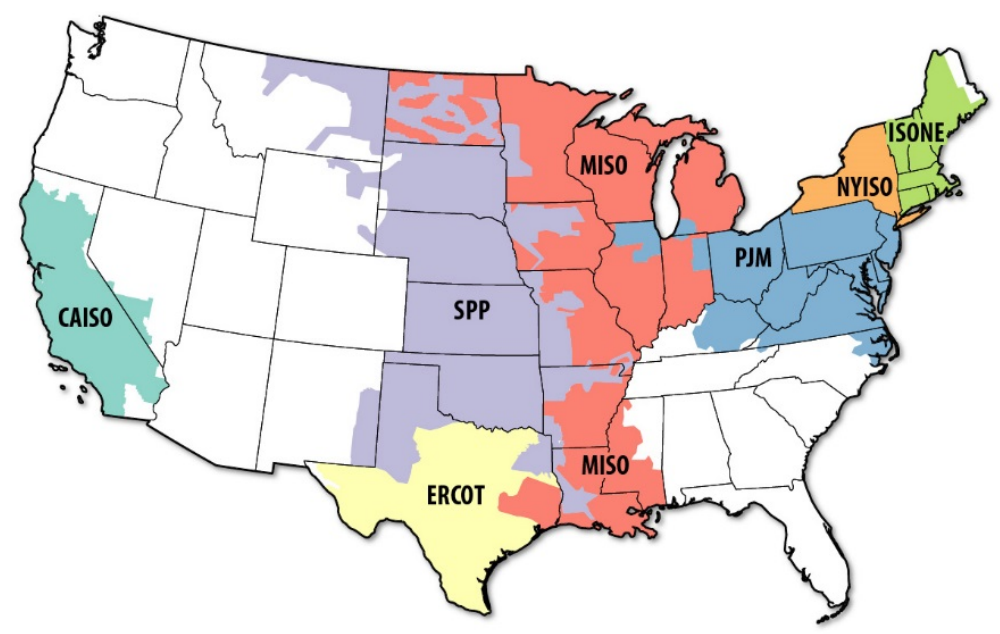

Figure 4. Map of regional transmission organizations and independent system operators

Source: Billy Roberts, NREL

\subsection{Benefits and Challenges of Financial PPAs}

Companies interviewed suggested several motivations for choosing a financial PPA. Similar to physical PPAs, signing a financial PPA does not require the company to invest capital in a renewable project. Also, companies have interest in financial PPAs because of the financial benefit; potential hedge value; and ability to source from new, large-scale projects.

Financial Benefit. Corporate customers have been signing financial PPAs primarily in regions where renewable energy is cost-competitive with traditional energy sources, and the majority of megawatts are being signed for wind. Although data on solar PPA prices (physical or financial) are difficult to obtain, Honeyman et al. (2016) noted that recent utility-scale solar PPAs have been signed in the range from $\$ 35 / \mathrm{MWh}-\$ 50 / \mathrm{MWh}$. Some data on utility-scale solar PPA prices have been published by the U.S. Department of Energy (Bolinger and Seel 2016). Trends show that utility-scale solar PPA pricing in four of five regions has been less than $\$ 50 / \mathrm{MWh}$, with the Midwest being less than $\$ 60 / \mathrm{MWh}$ (Figure 5). ${ }^{3}$ These prices represent PPAs with utilities as well as non-utilities.

\footnotetext{
${ }^{3}$ Pricing in Figure 5 includes the electricity and renewable energy certificates (RECs) bundled together; Bolinger and Seel (2016) exclude projects from their sample that sell RECs separately from the electricity.
} 


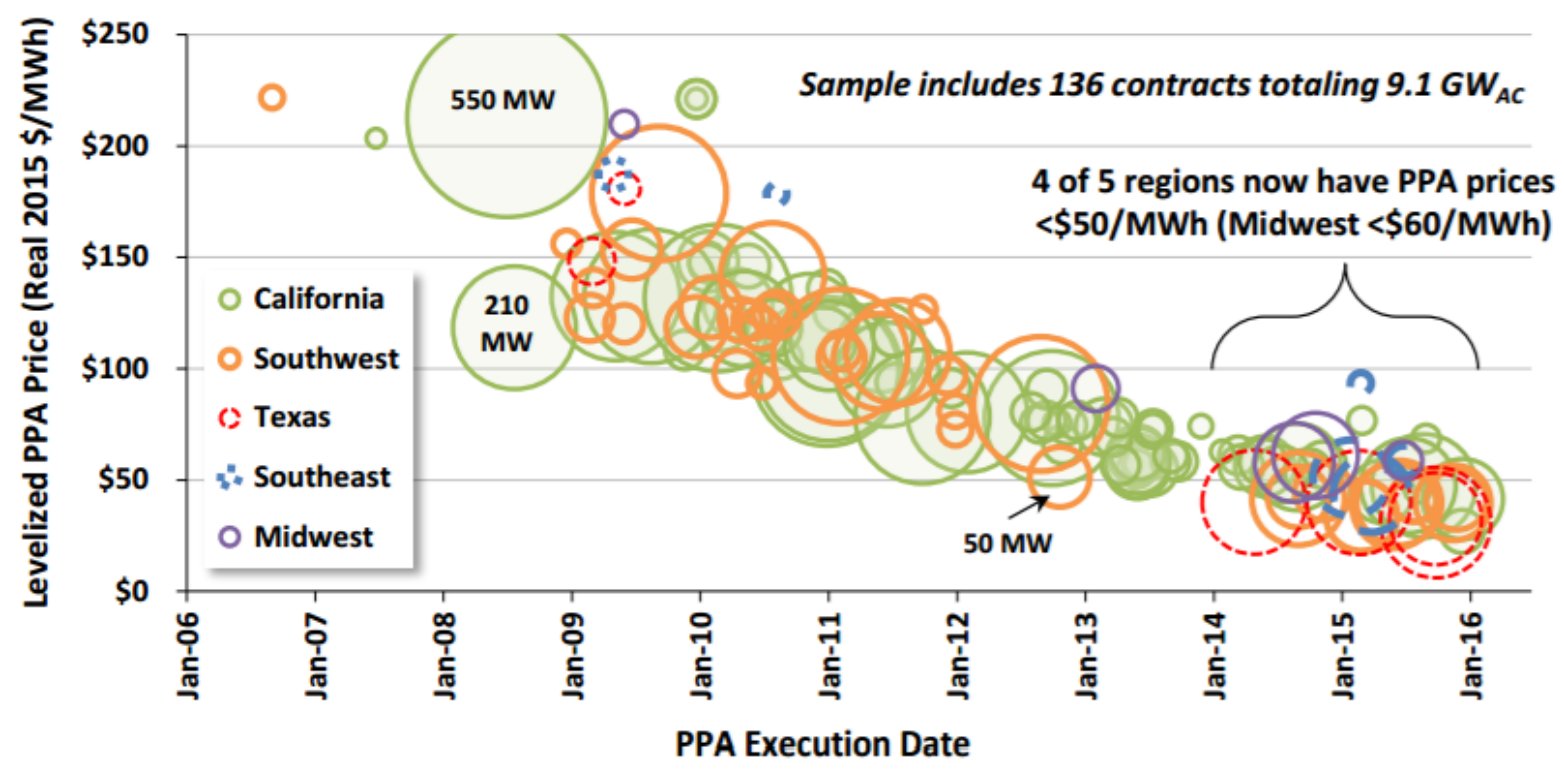

Figure 5. Levelized utility-scale solar PPA price.

Source: Bolinger and Seel (2016)

Historically, approximately $70 \%$ of financial PPAs by corporate customers (for any renewable technology) have been sited in the Electric Reliability Council of Texas (ERCOT) and the Southwest Power Pool (SPP). Following that, PJM and areas in the Southeast have seen the largest amounts of megawatts signed (Table 1).

Table 1. Concentration of Financial PPAs (any technology type) by Region, though July 2017

\begin{tabular}{lll}
\hline Region & MW & \% of Total \\
\hline $\begin{array}{l}\text { ERCOT and SPP } \\
\begin{array}{l}\text { California Independent } \\
\text { System Operator }\end{array}\end{array}$ & 3,320 & $67 \%$ \\
$\begin{array}{l}\text { PJM and Southeast } \\
\text { region }\end{array}$ & 482 & $12 \%$ \\
$\begin{array}{l}\text { Midcontinent Independent } \\
\text { System Operator }\end{array}$ & 134 & $10 \%$ \\
Southwest region & 75 & $3 \%$ \\
All other & 365 & $1 \%$ \\
\hline
\end{tabular}

Potential Hedge Value. When companies source from renewable projects located close to their electricity load, the project structure can create a hedge against rising electricity costs. The price the company pays to their utility should rise or fall in tandem with the price the renewable project receives in the wholesale market, assuming that the utility rates that the company pays track wholesale market rates. The farther the renewable project is from the company's demand, the greater the likelihood of an imperfect hedge. 
Contributing to New Project Development. Companies also mentioned their interest in being able to source from new, large-scale renewable energy projects. The average capacity for solar PPAs in 2015 and 2016 was $50 \mathrm{MW}$, with the average financial PPA being $60 \mathrm{MW}$. These large-scale projects are being used primarily by companies that have large, energy-intense data centers.

Companies suggested many barriers to financial PPAs, notably the level of energy market expertise and the risk and market exposure created by the contract structures. The risk and market exposure created by financial PPAs can make them difficult to evaluate. The potential benefits of a financial PPA derive from expectations of future wholesale market prices, which are challenging to forecast. Some companies noted that there is uncertainty about how higher penetrations of renewables will affect wholesale market prices. With this uncertainty, companies are gaining market exposure that they might not want.

Energy Market Expertise Requirements. Companies we spoke with noted that financial PPAs, because of their terms and structures, require executive approval. Executives from legal, finance, treasury, accounting, and other areas are typically involved, along with a sustainability and/or energy manager (PwC 2016; ACORE 2016). Company sustainability officers might find it difficult to identify up front who needs to be involved and to educate them. Some smaller companies we spoke with found that hiring an energy consultant well versed in financial PPAs was a key to enabling project approval. Also, although the process of signing a second financial PPA might be faster than the first one, changing market dynamics and profit risk might make executives more reluctant to sign additional financial PPAs.

Risk and Market Exposure. Financial PPAs must address issues of negative wholesale market prices and determine where the setline price is set. In the Electric Reliability Council of Texas, for example, wind generators have been able to sell at $\$ 0 / \mathrm{MWh}$ or less and still profit because of the production tax credit; however, corporations do not want to be responsible for the cost of a negative price. Provisions to address negative prices are addressed in the financial PPA. Financial PPAs must also determine where the settling price is set. Corporate customers typically want to minimize their risk and thus settle at the hub; however, if developers take on the risk, it may result in a higher electricity price than they are willing to accept. Some corporations might be willing to take more risk by settling at the node and then finding ways to hedge the risk (Chadbourne 2016).

\subsection{Solar Financial PPA Market Status}

This section reviews the status of solar financial PPAs within the context of the broader renewable PPA market. In total, off-site nonutility PPAs have resulted in 8,121 MW of demand through July 2017. A subset of this demand is for financial PPAs. The megawatts of financial PPAs signed by nonutility off-takers increased dramatically in 2015, to 3,199 MW, but it declined in 2016 to approximately 1,902 MW (Figure 6). Procurement in 2015 was likely higher because of uncertainty around the production tax credit and investment tax credit extensions and procurement by Google, which signed $669 \mathrm{MW}$ of financial PPAs in 2015. Overall, financial PPAs represented $65 \%$ of the non-utility PPA capacity signed through July 2017. 


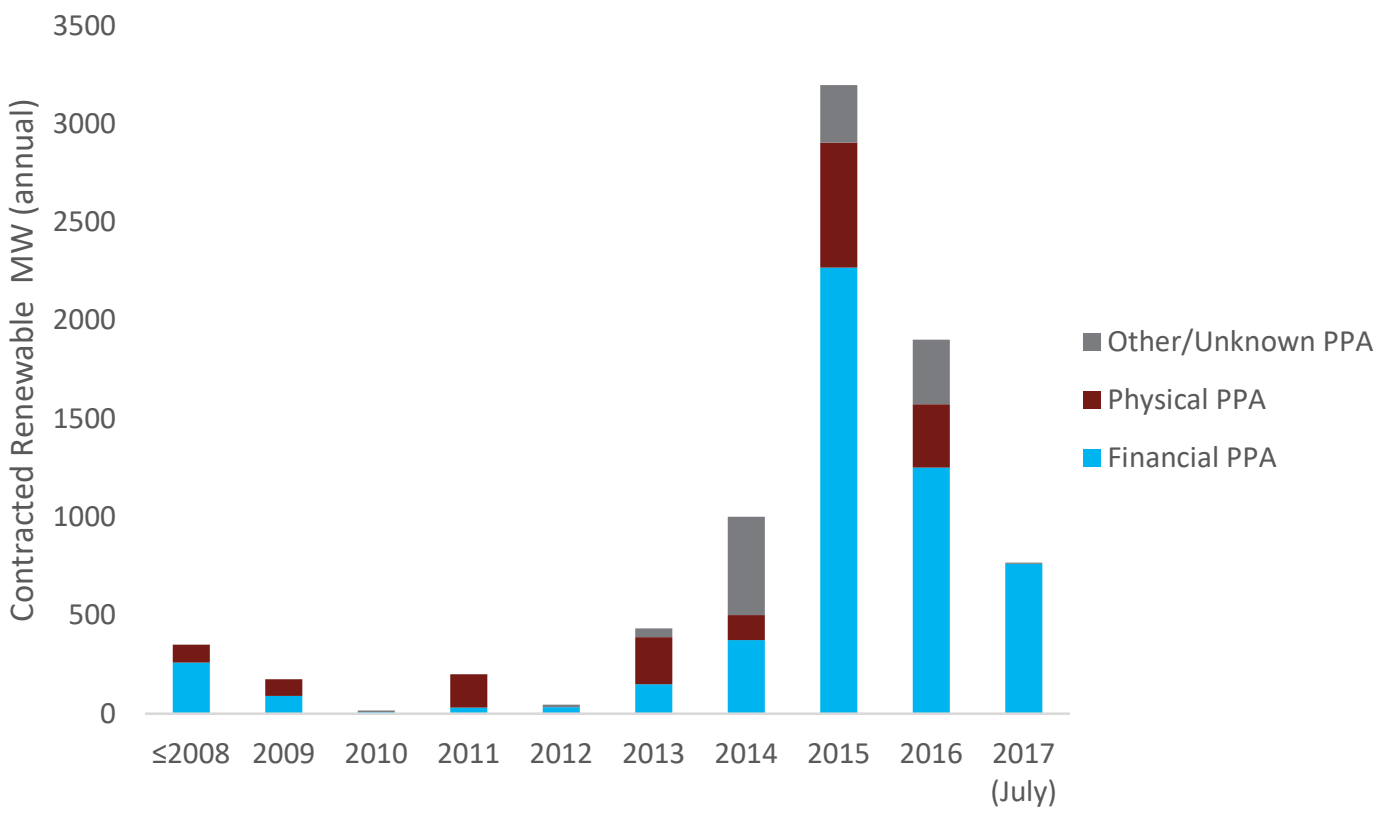

Figure 6. Corporate off-site PPAs (any technology) by contract type and signing year

Data from NREL and BNEF (2017)

Corporate off-site solar PPAs represent a smaller share of the overall PPA market, peaking at more than $800 \mathrm{MW}$ in 2015 and declining to approximately $300 \mathrm{MW}$ in 2016 (Figure 7). The year 2015 was dominated by four solar financial PPAs totaling more than $500 \mathrm{MW}$ in California.

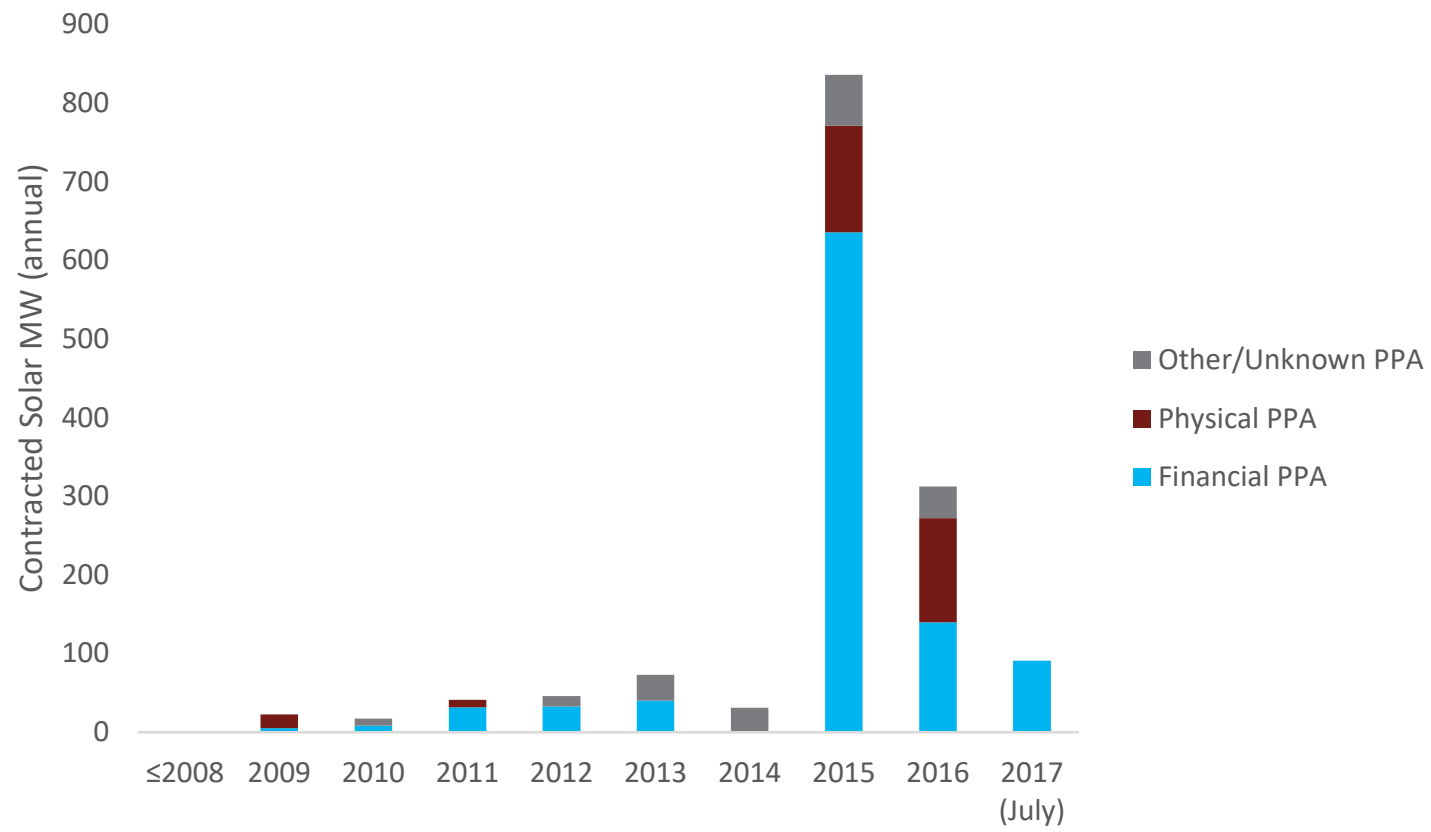

Figure 7. Corporate off-site solar PPAs by contract type and signing year Data from NREL and BNEF (2017) 


\subsection{Case Study: Aggregate Solar Financial PPA}

Financial PPAs are complex transactions, which to date have largely limited their uptake to institutions that have larger loads, the ability to absorb transaction costs, and the ability to enter into long-term contracts; however, in 2016, a financial PPA aggregation was signed by three entities that have smaller loads. The Massachusetts Institute of Technology, Boston Medical Center, and the Post Office Square Redevelopment Corporation signed a 25-year financial PPA for $60 \mathrm{MW}$ of solar located in North Carolina (Table 2).

Table 2. Shares of the Aggregated Solar Financial PPA

\begin{tabular}{lll}
\hline Off-Taker & Share of Solar Array & Percentage of Load Covered \\
\hline $\begin{array}{l}\text { Massachusetts Institute of } \\
\text { Technology }\end{array}$ & $73 \%(44 \mathrm{MW})$ & $40 \%$ \\
Boston Medical Center & $26 \%(16 \mathrm{MW})$ & $100 \%$ \\
$\begin{array}{l}\text { Post Office Square } \\
\text { Redevelopment Corporation }\end{array}$ & $<1 \%(<1 \mathrm{MW})$ & $100 \%$ \\
\hline
\end{tabular}

Source: Chandler (2016)

The aggregation was facilitated by A Better City, a nongovernmental organization interested in helping to reduce carbon-dioxide emissions in Boston's commercial real estate and business sectors; and by CustomerFirst Renewables, an energy procurement consulting firm. CustomerFirst worked on behalf of the buyers to design, structure, and lead the negotiation of the PPA. Of the 41 projects proposed in a competitive solicitation process, the buyers selected a North Carolina-based solar array because it offered a larger contiguous area of land on which to site the project than that available in the Northeast, the local companies handling the design and installation had a proven track record of building and operating similar facilities, and North Carolina's grid had higher greenhouse-gas emissions than the Northeast (Chandler 2016)

It took nine months to complete the transaction. Key lessons from the aggregated purchase included engaging as many potential off-takers as possible (because some organizations might originally express interest but then back out) and working with organizations that have energy expertise and can educate each organization up front to minimize transaction times (A Better City 2017).

\subsection{PPA Outlook}

Participants expect that the market for PPAs will continue to grow. Although overall signed PPA capacity declined in 2016 from the record-high 2015 levels, corporate customers looking to meet their renewable energy commitments will likely seek PPAs for projects that can take advantage of federal tax credits before those tax credits begin to phase down. For solar PPAs, this means that projects must begin construction in 2019 to receive a 30\% investment tax credit.

In addition to likely increased PPA signings, market participants noted that PPA deals going forward are more likely to be signed at the hub. This will shift risk to the developer, but these might be passed on to the corporate off-taker. Developers can manage the basis risk with financial products. 
To make financial PPAs available to a larger set of purchasers, developers and other stakeholders will need to continue to improve aggregation capabilities and the ease of financing projects for companies that have smaller loads. 


\section{Retail Choice}

This section explores how retail choice programs work, followed by a discussion of the benefits and challenges of this approach for procuring off-site solar. The section also discusses the status of retail choice, in both states that have full and partial programs, with a focus on MGM's exit of NV Energy. It concludes with a discussion of the outlook for this pathway.

\subsection{How Retail Choice Programs Work}

In retail choice programs an eligible customer can select either a competitive energy supplier or a regulated utility to serve their load. If a customer chooses the competitive energy supplier, they can negotiate the terms of the electricity contract to include more renewable energy than offered by a regulated utility and a variety of energy-efficiency or demand response services. The competitive supplier is then charged with procuring electricity at the established rate to serve that corporate customer. The supplier must also work with the regulated utility that provides transmission and distribution services. These and other grid-related costs are price regulated and included in a corporation's bill in addition to the negotiated electricity cost generated by the competitive supplier. Subject to the length and terms of a corporation's contract with a competitive supplier, the customer is free to shop for lower priced energy from alternative suppliers. If a corporate customer does not select a competitive supplier, they might be defaulted into the provider of last resort, typically a regulated utility.

\subsection{Benefits and Challenges of Retail Choice}

Retail choice programs can be attractive to corporations that want to procure solar to meet their electricity needs. Having access to several electricity suppliers offers corporations the opportunity to select a supplier that offers the best rate or set of services that meet the needs of the corporate customer. This could include a competitive supplier that offers a solar product. If more than one supplier offers a corporation the services they need, the company can select the least-cost supplier.

Another important benefit of retail choice is the ability of a company to negotiate the length of the contract with the supplier. A company might negotiate a shorter term contract to access the market sooner in the event technology innovation and cost reductions appear in the market. In comparison, a company might select a longer term contract to lock in a fixed rate to offer price certainty or a hedging opportunity.

Once the corporation enters a contract with a competitive supplier, the supplier then works with the utility to ensure that the customer receives firm, reliable power from the grid. This includes working with the regulated utility to provide the corporation with one bill that includes the cost of transmission, distribution, and electricity. Thus, the service relationship is not significantly different from that of a traditional regulated utility, limiting any additional costs for participating in retail choice.

Corporations face some challenges when exploring retail markets. Retail choice is limited to 21 states, so corporations located in the other 29 states might not have access to competitive 
suppliers (See Figure 8). Public utilities commission staff interviewed in this study confirmed this barrier, at least for the utilities they oversee. ${ }^{4}$

In states and utility jurisdictions where retail choice is available, there are other challenges with retail choice and procuring solar. Although suppliers might participate in relevant markets, they might not offer solar products that fit the needs of corporate customers. These products might be too costly, or they might not include ownership of the associated environmental attributes or RECs. If a solar product is not available, corporations might still generate savings by selecting a competitive supplier. If so, the corporation could use that savings to reinvest in solar to achieve their objectives.

Finally, corporations that participate in retail markets can be subject to energy price volatility. Corporations that select shorter term contracts with competitive suppliers might face higher electricity costs when those contracts end. This same issue can be a concern for longer term contracts as well. If regulated utilities are able to limit cost increases by spreading them among more customers, participating in the retail market might cause corporate customers to pay higher rates overall than might have been the case otherwise.

\subsection{Retail Choice Market Status}

The ability of corporate customers to participate in retail markets is influenced by the scope and structure of each state's retail choice program. To date, 21 states offer some form of retail choice, ranging from full access, in states such as New York; to more limited retail choice for certain corporate customers, which is the case in Oregon (Figure 8).

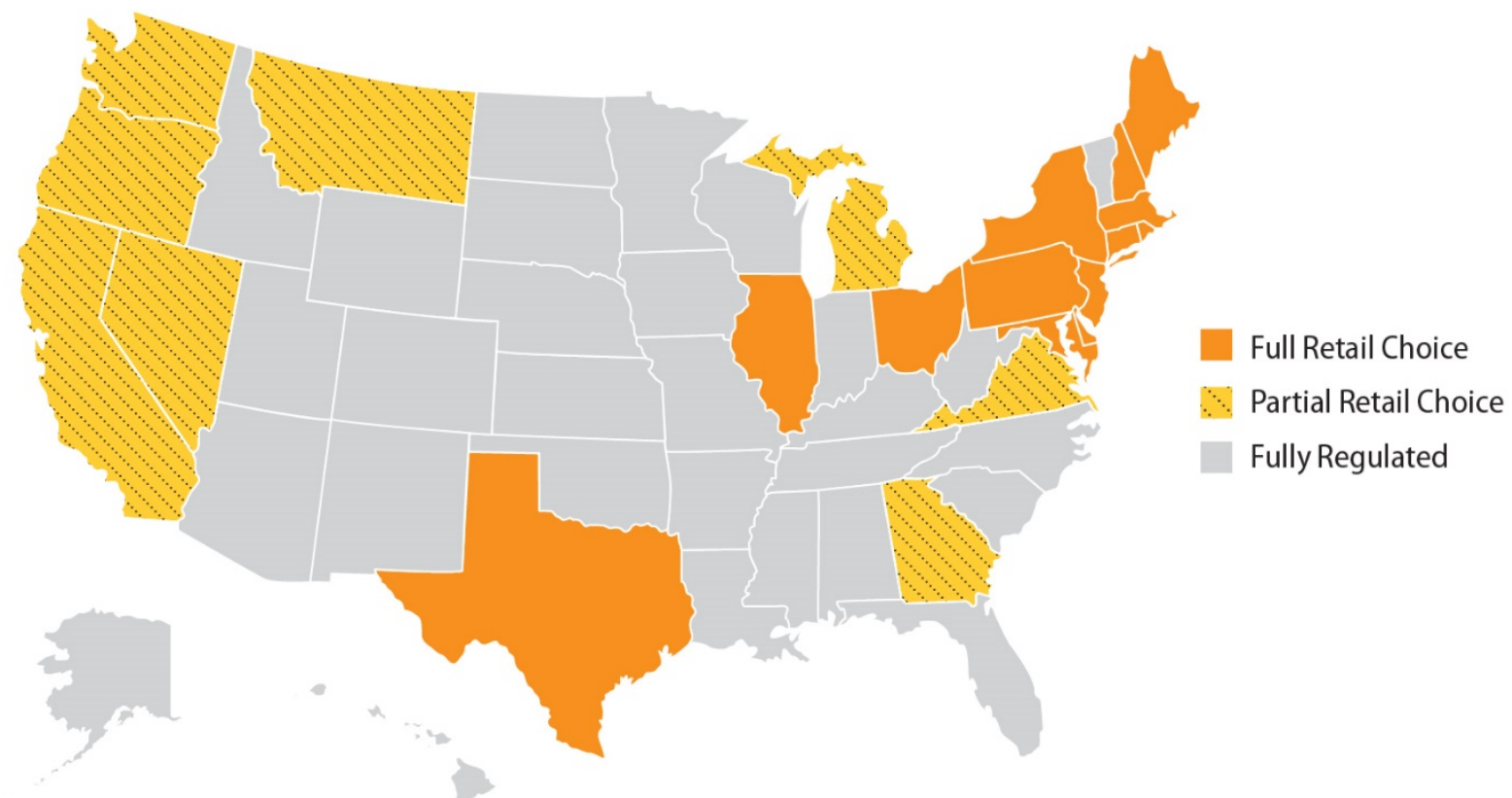

Figure 8. Retail choice options for commercial and industrial customers

\footnotetext{
${ }^{4}$ It is possible that corporations served by public utilities or cooperatives might have more options to pursue retail choice in these states.
} 
Corporations located in 13 states and Washington, D.C. have full access to retail choice and thus the opportunity to purchase electricity from their preferred supplier and technology source, such as solar (See Figure 8). These corporations also have the opportunity to switch providers, based on price or other factors. According to the U.S. Energy Information Administration (2016), approximately $45 \%$ of 2015 commercial and industrial (C\&I) retail sales among these states were from retail service providers. As much as $64 \%$ of Texas's C\&I load is served by these providers, whereas the lowest rate is in New York, at 31\% (Figure 9).

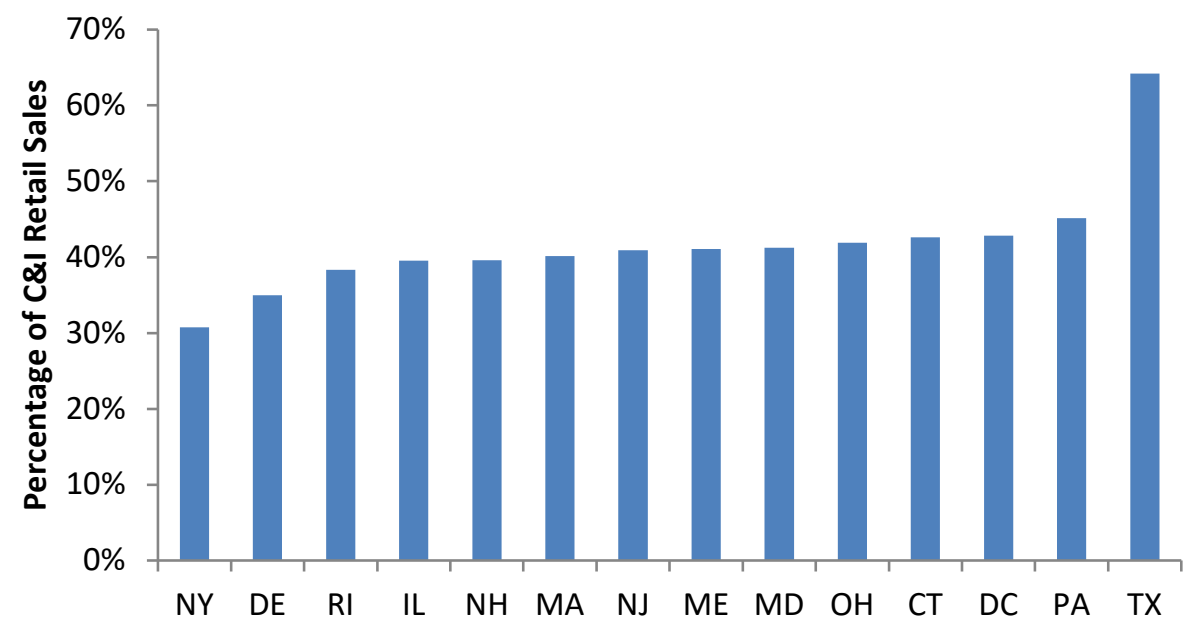

Figure 9. Percentage of $\mathbf{2 0 1 5}$ retail sales sourced from retail service providers in restructured markets

Source: U.S. Energy Information Administration (2016)

In comparison, only some corporations have the opportunity to access retail markets in the eight states that have partial retail choice. ${ }^{5}$ Among these states, in Montana a high of $23 \%$ of 2015 C\&I sales were provided by retail service providers, whereas in Georgia the U.S. Energy Information Administration (2016) did not identify any retail sales from these entities (Figure $10)$.

\footnotetext{
${ }^{5}$ In Nevada, C\&I customers must first receive service from a regulated utility, prior to joining the retail market. The Silver State Energy Association (SSEA) that provides service to Boulder City, Nevada also accesses the retail market (SSEA n.d.; 2001 Statutes of Nevada; PUCN 2008; EIA 2016).
} 


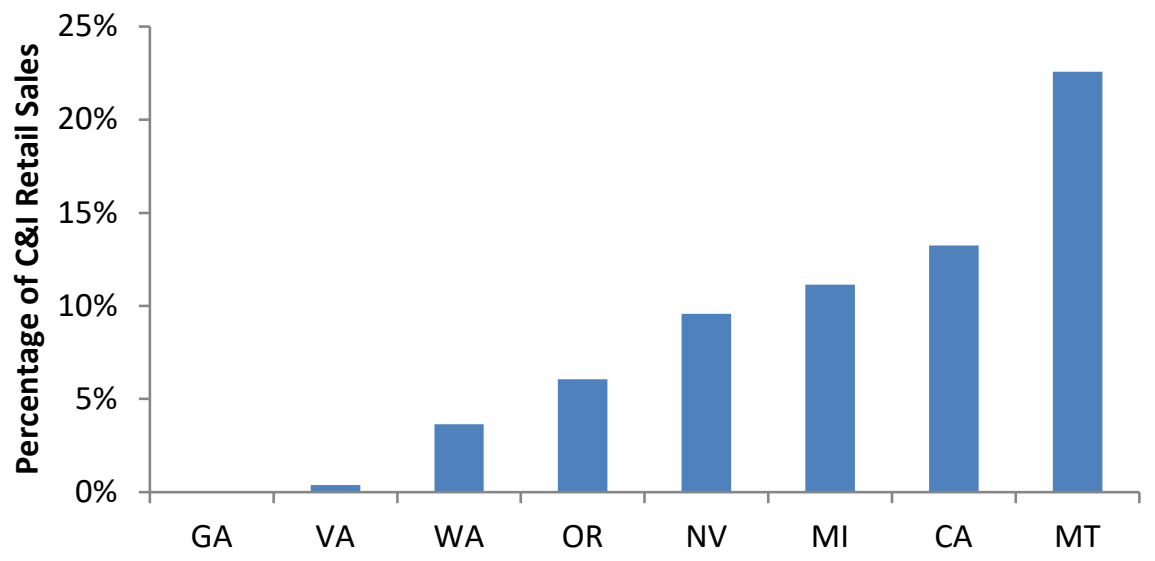

Figure 10. Percentage of 2015 retail sales sourced from retail service providers in partial retail choice markets

Source: U.S. Energy Information Administration (2016)

The more limited sales in these states is the result of customer class and program cap restrictions. Typically, these narrower programs are limited to certain customer classes or are capped and fully subscribed. Table 3 compares these partial retail choice programs based on the customers that are able to participate.

Table 3. Comparison of Partial Retail Choice Programs by State

\begin{tabular}{llll}
\hline State & $\begin{array}{l}\text { Eligible Customer } \\
\text { Classes }\end{array}$ & Utility & Program Cap \\
\hline California & Any customer & Investor-owned utilities & $12 \%$ of load \\
Georgia & New load $\geq 900 \mathrm{~kW}$ & $\mathrm{~N} / \mathrm{A}$ & $\mathrm{N} / \mathrm{A}$ \\
Montana & Load $\geq 5 \mathrm{MW}$ & $\mathrm{N} / \mathrm{A}$ & $\mathrm{N} / \mathrm{A}$ \\
Michigan & Any customer & Certain utilities & $10 \%$ of retail sales \\
Nevada & Load $>1 \mathrm{MW}$ a & N/A & N/A \\
& Nonresidential & PacifiCorp and Portland & Portland General Electric: \\
Oregon & customers & General Electric & MW M PacifiCorp: 175 \\
Virginia & Load $\geq 5$ MWc & N/A & N/A \\
Washington & Case-by-case basis & Puget Sound Energy & N/A \\
\hline
\end{tabular}

a Threshold for customer to petition to exit regulated utility service.

b The caps are set by the Oregon Public Utility Commission and could be adjusted in the future.

c Two or more nonresidential customers can aggregate their demand ( $\geq 5 \mathrm{MW}$ ) and petition for retail choice access

${ }^{d}$ All of the customers granted access to retail choice have had significant load.

First, three states have outright caps on participating in retail choice programs, including California, Michigan, and Oregon. California limits retail choice among the state's three largest investor-owned utilities to approximately $12 \%$ of load (California Public Utilities Commission, 
n.d.). These program caps have been met (California Public Utilities Commission 2016), and utilities internally manage wait lists. In 2015, the cumulative demand wait-listed for retail choice among the three utilities was reported to exceed 6 TWh (Mulkern 2015). ${ }^{6}$ Similarly, Michigan established a $10 \%$ weather-adjusted retail sales cap on its program. In 2016, more than 6,600 customers representing $11 \mathrm{TWh}$ of load were on the wait list and interested in joining retail choice should capacity under the cap become available (Michigan Public Service Commission n.d.). In contrast, Oregon limits retail choice to a total capacity of 475 average MW for nonresidential customers (Public Utility Commission of Oregon 2015; Public Utility Commission of Oregon 2017). These caps have not yet been reached and both utilities continue to offer access to retail choice markets on 1-, 3-, and 5-year schedules (Pacific Power 2017; Portland General Electric 2017). ${ }^{7}$ As a result, retail choice might not be available for corporations that are located or interested in locating in California or Michigan, though they could participate in retail choice in Oregon.

Washington does not have a direct access cap, but it limits retail choice access to those customers in Puget Sound Energy's territory. Washington also does not specify a minimum load requirement for customers, rather retail choice eligibility is determined on a case-by-case basis (Puget Sound Energy 2017). To date, all of the companies granted retail choice have had significant electrical demand. Corporations located in other service territories cannot access retail markets in Washington.

The remaining four states limit access to retail choice to corporations that have new load and/or only if that load exceeds certain thresholds. Virginia and Montana have established the highest threshold for retail choice access, at $5 \mathrm{MW}$ or more (Commonwealth of Virginia State Corporation Commission 2017, Montana Code Annotated 2015). In comparison, Georgia's threshold is the lowest, at $900 \mathrm{~kW}$ or more; whereas in Nevada customers that have demand more than $1 \mathrm{MW}$ can petition to exit utility service for retail choice (2001 Statutes of Nevada). Therefore, corporations with significant electricity demand in these states might be able to access retail markets, but facilities that have a smaller load might not.

If a large customer initially decides to take utility service in Georgia, the customer is prohibited from further access to retail choice. In comparison, Nevada, Virginia, and Washington's programs allow existing large customers to exit utility retail service. In Nevada and Washington, customers can leave a utility's service after receiving regulatory approval and paying an exit fee that reimburses the utility for expenses incurred to serve that corporation's load. ${ }^{8}$ These fees can be large, as illustrated by the case study that follows, depending on how big the customer is and how recently the utility made investments to serve that load. In comparison, Virginia does not

\footnotetext{
${ }^{6}$ California also allows corporate customers to participate in community choice aggregation (CCA) programs where one or more municipal governments adopt a communitywide electricity buyers' program (2002 Statutes of California). CCA programs are not a focus of this study, but for more information on this market see O'Shaughnessy et al. 2016.

${ }^{7}$ Portland General Electric confirmed that 214.6 aMW of capacity is participating in their direct access program, leaving a total of 85.4 aMW available under the cap.

${ }^{8}$ See regulatory language at https://www.leg.state.nv.us/NRs/NRS-704B.html and https://www.utc.wa.gov/docs/Pages/DocketLookup.aspx?FilingID=161123.
} 
require an exit fee. However, if a corporation wants to return to utility service it must submit written notice of its intent to do so five years in advance. ${ }^{9}$

\subsection{Case Study: MGM Exits Nevada Energy Territory for Wholesale Market}

As of July 2017, MGM Resorts International (MGM), Wynn Resorts, Switch, and Caesars Entertainment Corporation have either left or been approved to leave NV Energy's service territory (Ryan 2017), and Microsoft has been approved to partially leave Puget Sound Energy's service in Washington for the retail market (Microsoft News Center 2017). ${ }^{10}$ This section discusses the process by which corporations can exit utility service by analyzing the exit of MGM from NV Energy's territory as a case study. The focus is on the process used and whether it can be applied in other contexts.

Corporations are granted the authority to leave a utility's service territory as stipulated in the Nevada Revised Statutes 704B.310. ${ }^{11}$ To begin the process, a corporation (with $1 \mathrm{MW}$ of load or more) must submit an application to the State of Nevada Public Utilities Commission (PUCN) 180 days prior to their intended exit. The application must reference the electricity supplier with which the corporation expects to contract, terms of the agreement, quantity and source of generation, price, and any other information the commission deems relevant. After the complete application is filed, the PUCN must provide public notice of the application and offer an opportunity for a public hearing.

Before approving the application, the PUCN must determine that the transaction will not be contrary to the public interest or violate other provisions of the law. When evaluating compliance with the public interest, the commission must weigh impacts to ratepayers, system reliability, and the overall energy supply in the state. To mitigate any negative impacts on the public interest, the commission can require the corporation to pay an exit fee designed to recoup unrecovered costs from the utility related to serving that corporation's demand.

MGM submitted their application to exit NV Energy's utility service territory on May 12, 2015 (Schmidt 2015). MGM confirmed the company's intention to enter into an agreement with Tenaska Power Services to secure new electricity generation. Although MGM would source electricity from a third party, they would continue to rely on NV Energy's transmission. Thus, the application also stated MGM's intent to negotiate with the utility to secure a distribution-only service rate (Schmidt 2015).

PUCN staff analyzed the impact on public interest and submitted a report to the commissioners on September 10, 2015 (PUCN 2015a). The PUCN then held a hearing on the application and its impact analysis on October 21, 2015, and issued a final decision on December 2, 2015. The order initially required MGM to pay an $\$ 87$ million impact fee as a condition of the application's approval, among other requirements (PUCN 2015b). A calculation of MGM's annual electricity

\footnotetext{
${ }^{9}$ See regulatory language at http://aw.lis.virginia.gov/vacode/title56/chapter23/section56-577/.

10 The agreement stipulates that $80 \%$ of Microsoft's eligible load will be served by a competitive supplier and the remaining 20\% will be served by Puget Sound Energy (Microsoft News Center 2017).

${ }^{11}$ See regulatory language at https://www.leg.state.nv.us/NRs/NRS-704B.html.
} 
cost burden helps put this fee into perspective: as a customer of NV Energy, MGM reportedly accounted for $4.86 \%$ of the utility's sales (Whaley 2016a). Nevada industrial customers paid an average retail rate of $\$ 0.065 / \mathrm{kWh}$ in $2015 .{ }^{12}$ This suggests that MGM paid approximately $\$ 68$ million for electricity among its operations in 2015.

MGM announced its intention to comply with the order on January 4, 2016, while it filed a petition for reconsideration to reduce the $\$ 87$ million impact fee (Schmidt 2016a). Despite this fee, MGM personnel reportedly justified the action by asserting that having control over supply was important given low wholesale market rates (Rothberg 2016). In addition, MGM considered regulated utilities less able to leverage innovations in the energy market that can further drive down costs. MGM became a distribution-only NV Energy customer on October 1, 2016, paving the way for MGM to procure its own electricity on the wholesale market (Schmidt 2016b). MGM is required to meet Nevada's renewable portfolio standards requirements and has reportedly expressed interest in utility-scale solar (Rothberg 2016).

In response to MGM's petition for reconsideration, on May 24, 2017 the PUCN approved a \$16 million impact fee credit for MGM (PUCN 2017). The credit was granted because the initial impact fee was set based upon a February 1, 2016 exit, while MGM continued to pay full retail rates to NV Energy until their exit October 1, 2016 (PUCN 2017).

As noted, MGM is not the only entity to leave NV Energy's territory. Wynn Resorts concurrently filed to exit the utility and paid a $\$ 16$ million exit fee (Whaley 2016b). Together, these two corporations represented 6\% of NV Energy's load (Rothberg 2016). In November 2016, Caesars Entertainment Corporation, which operates 14 casinos, filed to exit NV Energy's southern and northern territories in favor of wholesale markets, and it has since agreed to pay a \$47.5 million exit fee (Schmidt 2016c; Schmidt 2016d; Ryan 2017).

Although some companies are following MGM's lead, this pathway might not be feasible for all corporate customers because of the significant time and resource constraints required as well as the exit fees. Complex financial and energy market analyses are needed to determine the possible net benefit of an exit and whether the imposed exit fee might be justified. In addition, the company exiting will need to pay legal fees, develop the application, and participate in a potentially lengthy regulatory proceeding. Not all corporations have the capital to conduct these analyses and pay associated impact fees to exit the utility. For example, after the PUCN confirmed the impact fee for Las Vegas Sands Corporation, the corporation no longer pursued the exit (Rothberg 2016). Thus, although this pathway is available in Nevada, Virginia, and Washington, not all corporations might be able or willing to carry out the requirements to exit their utility service provider.

\subsection{Retail Choice Outlook}

Retail choice for corporate customers is allowed in 13 states. Corporations that locate in these states can pursue their own electricity generation sources, including solar. In eight additional

\footnotetext{
12 This consumption is based on NV Energy's total C\&I electricity sales, which are available at http://www.eia.gov/electricity/state/Nevada/xls/nv.xlsx.
} 
states, some corporate customers have access to wholesale markets. This access is not open to all commercial customers, however, as is the case in California, Michigan, and Oregon.

For the other 29 states, statutes prohibit C\&I participation in retail markets absent an arrangement with the utility. To open this pathway, legislators would need to enact new statutes that allow some form of retail choice. ${ }^{13}$ Electricity market restructuring discussions are underway in Nevada (Associated Press 2017). In comparison, Michigan enacted SB 437 in 2016, which maintains its $10 \%$ cap on retail choice while establishing a generation capacity charge for new customers among other stipulations. ${ }^{14}$ At the time of this writing, similar legislation has not been enacted to pursue electricity market restructuring or retail choice in other states.

As a result, the current landscape might hold true going forward, wherein corporations that locate in the aforementioned 21 states have an opportunity to participate directly in retail markets but those in the other 29 do not. One trend worth watching is the ongoing activity in Nevada and Washington for large corporate customers to exit utility service territories; however, the relatively high cost of this activity might limit the appeal of this approach. It is not just high costs that might limit this pathway. In Virginia, low electricity rates and the price stability offered by the incumbent utility, coupled with the 5 year lag time between a customer exiting and returning, has resulted in few customers existing. Nevertheless, these three states offer a pathway for certain already-operating corporate customers to pursue retail generation that is not currently available in other traditionally regulated states.

Finally, although corporations can have retail choice in 21 states, these corporations might not all be interested in procuring renewable generation, such as wind or solar. The low cost of natural gas is driving down wholesale market costs, and generation from these existing facilities can be lower than the cost of new or existing renewables (Bolinger and Seel 2016). Nevertheless, corporations that are interested in achieving renewable generation targets might have an easier path toward meeting these goals in states that offer retail choice rather than in those that are traditionally regulated.

\footnotetext{
${ }^{13}$ In at least two states (Utah and Missouri), very specific legislation has been passed to allow certain customers to access wholesale markets (see https://le.utah.gov/xcode/Title54/Chapter3/54-3-S32.html and http://www.moga.mo.gov/mostatutes/stathtml/09100000261.html). In Utah, the eligible customer was an industrial facility with a large power plant: https://le.utah.gov/xcode/Title54/Chapter2/54-2-S1.html?v=C54-2S1_2016051020160510; Missouri granted the exception for an aluminum smelting facility.

${ }^{14}$ See bill language at http://legislature.mi.gov/documents/2015-2016/publicact/pdf/2016-PA-0341.pdf.
} 


\section{Utility Partnerships: Green Tariffs and Bilateral Contracts}

This section explores how utility partnerships work, focusing on green tariffs and bilateral contracts, followed by a discussion of the benefits and challenges of utility partnerships for procuring off-site solar. The section then discusses the status of utility partnerships, with a case study on Alabama Power's Renewable Procurement Program. It concludes with a discussion of the outlook for utility partnerships.

\subsection{How Utility Partnerships Work}

Utility partnerships are one way that corporate customers in regulated states can access large offsite solar. State public utility regulators must approve utility rate structures and programs to ensure that programs are in the best interest of all ratepayers. If a program is not in the interest of all ratepayers, the utility must demonstrate that program costs are not borne by nonparticipating customers.

Since the 1990s, many regulated utilities have received approval to offer renewable energy to corporate customers through green pricing programs (O’Shaughnessy et al. 2016). These programs offer corporations and smaller customers the option to purchase renewable energy; however, these products have nearly always come with a price premium and do not offer participants long-term energy price hedging. Typically they also have had low percentages of solar in their green product mix (O'Shaughnessy et al. 2016).

In contrast to these earlier offerings, new green tariff programs and bilateral contracts allow corporate customers to procure renewable energy from a specified project and receive its associated RECs under a long-term (such as 20 years) rate agreement with the utility. Some utilities have not pursued green tariff programs, but they have received approval for bilateral, one-off agreements with certain corporate customers. The difference between the two approaches is that green tariff programs are broadly available to corporate customers, whereas corporations might need to seek out bilateral agreement opportunities.

\subsection{Benefits and Challenges of Utility Partnerships}

Utility partnerships, both green tariffs and bilateral contracts, offer a variety of benefits to corporations. First, utilities have expertise in power procurement and operation, whereas corporations typically do not have the in-house staff to effectively serve the same role.

Moreover, corporate leadership approval is typically necessary at each stage in the process, from designing a request for proposal to signing a contract with a project developer. Receiving these approvals can take time. Having the utility manage the program can thus reduce administrative costs to the corporation; however, corporations would still need to evaluate the terms of the green tariff and ensure that the contract meets corporate objectives.

Second, utilities can aggregate corporate customer load to build larger projects that leverage economies of scale. Once a corporation participates in a green tariff program, typically the customer also benefits from predictable pricing and ownership of the RECs associated with the project. 
Finally, the corporate customer continues to receive power from the grid. As such, the corporation does not need to address issues relating to the variability of solar. Rather, the utility ensures that the corporation receives sufficient electricity to meet demand.

Some challenges are associated with these types of partnerships. First, when creating a new green tariff, utilities must demonstrate to regulators that nonparticipating customers are not negatively impacted; or, if nonparticipating customers are impacted, they must demonstrate that this action is in the public interest. This means that all costs to develop and administer the green tariff must be allocated to participating customers. In some cases, this results in tariff structures with higher rates.

Second, determining the appropriate price and credit for the renewable resources used can be challenging. Some corporate customers have expressed concerns that utilities are inflating the costs of administering these programs while limiting the generation and capacity credits that subscribers receive for their renewable purchase.

Third, these partnerships often require corporations to sign on to long-term contracts that can have associated market risks. ${ }^{15}$ One concern of potential green tariff subscribers is that the contracted, fixed prices for renewable projects today might exceed wholesale market rates in the future. Some corporations might be uncomfortable with these long-term commitments given uncertainties around long-term wholesale market prices. In comparison, those that are willing to take on this risk might want more control over the contracting process to negotiate terms directly with developers to minimize exposure. Regardless of which entities bear this risk, corporations are concerned about contract exit fees, which vary among programs. Some exit fees are associated with the remaining net present value of the project, whereas others are not clearly defined.

Fourth, while corporations may be able to select the source of the renewable energy under some green tariffs and bilateral agreements, in some cases the resource is selected by the utility. Utility selection may not provide the cost or other benefits sought after by potential subscribers.

Finally, utility-managed programs are still emerging, and efforts to design best practices are ongoing (Edison Electric Institute, World Resource Institute, and World Wildlife Fund n.d.). Nevertheless, relatively few utilities offer these programs or have experience devising bilateral agreements. Thus, corporate access to solar via utility-managed programs is still limited.

\subsection{Utility Partnership Market Status}

NV Energy was the first utility to propose a green tariff program, and regulators approved it in 2013. Since then, utilities in 16 other states have begun to offer corporate customers the option to procure renewables through special green tariffs or bilateral contracts (Figure 11). So far, utilities among 11 states have adopted or are pursuing green tariff programs, whereas others in 6 states have received approval for at least one bilateral agreement with a corporate customer.

\footnotetext{
${ }^{15}$ Some newer green tariffs offer shorter-term agreements, though at added cost.
} 


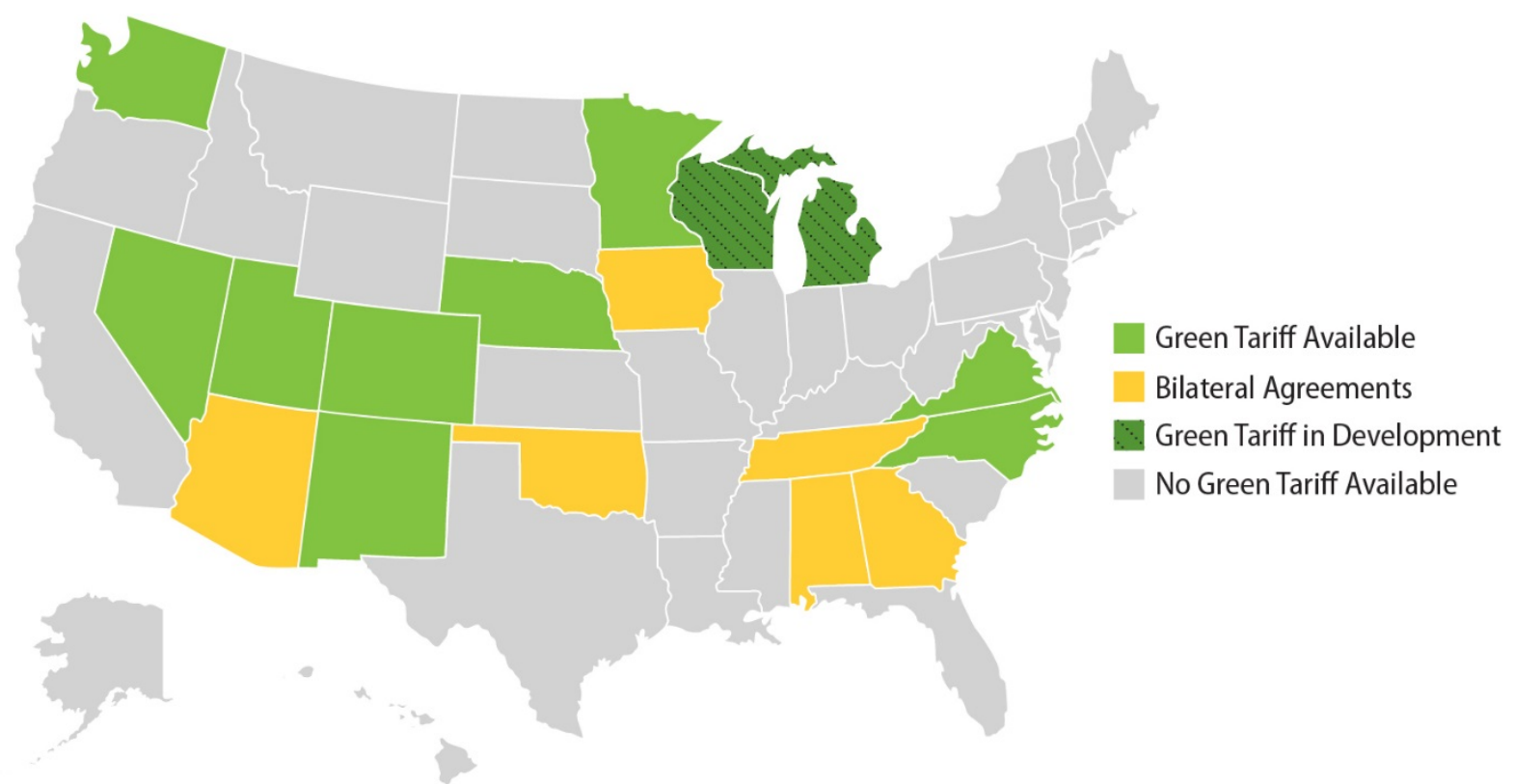

Figure 11. States that offer utility-scale purchasing options

To date, utilities among nine states have approved green tariff programs available to certain corporate customers. These tariffs vary among several key components, including program caps, eligible participants, contract requirements, and REC treatment (Table 4). For example, NV Energy's program is capped at $250,000 \mathrm{MWh}$, participation requirements vary depending on where the corporation is located, and contracts must exceed 2 years (Tawney et al. 2017). In comparison, Xcel Energy's tariff program in Minnesota is capped at 75 MW (25 MW solar), there are no limitations based on customer location, and corporations can select monthly, 5-year, or 10-year contracts (Tawney et al. 2017). 
Table 4. Comparison of Selected Approved Utility Green Tariff Programs

\begin{tabular}{|c|c|c|c|c|c|c|}
\hline Utility & $\begin{array}{c}\text { Eligible } \\
\text { Participants }\end{array}$ & $\begin{array}{l}\text { Potential Cost } \\
\text { Savings }\end{array}$ & $\begin{array}{l}\text { Length of } \\
\text { Contract }\end{array}$ & $\begin{array}{c}\text { REC } \\
\text { Treatment }\end{array}$ & $\begin{array}{c}\text { Enrollment } \\
\text { Period and } \\
\text { Program Limits }\end{array}$ & $\begin{array}{l}\text { Early Exit } \\
\text { Fees }\end{array}$ \\
\hline $\begin{array}{l}\text { Duke Energy } \\
\text { (NC) }\end{array}$ & $\begin{array}{l}\text { Certain classes of } \\
\text { large customers } \\
\text { with new load }\end{array}$ & $\begin{array}{l}\text { Credit capped } \\
\text { at renewable } \\
\text { energy cost, so } \\
\text { no cost savings } \\
\text { potential }\end{array}$ & $5-10$ years & $\begin{array}{l}\text { RECs owned } \\
\text { by/retired for } \\
\text { customer }\end{array}$ & $\begin{array}{l}\text { Tariff currently } \\
\text { expired after } 3- \\
\text { year pilot period; } \\
\text { legislation passed } \\
\text { to modify and } \\
\text { extend the } \\
\text { program }\end{array}$ & $\begin{array}{l}\text { Equal to the net } \\
\text { present value } \\
\text { of remaining } \\
\text { PPA cost }\end{array}$ \\
\hline $\begin{array}{l}\text { Dominion } \\
\text { Energy } \\
\text { Virginia (VA) }^{\mathrm{a}}\end{array}$ & $\begin{array}{l}\text { Certain classes of } \\
\text { large customers } \\
\text { with peak demand } \\
>5 \mathrm{MW} \text { and } \\
>85 \% \text { load factor }\end{array}$ & $\begin{array}{l}\text { Depends on } \\
\text { market rates }\end{array}$ & At least 3 years & $\begin{array}{l}\text { No RECs } \\
\text { involved; } \\
\text { renewable } \\
\text { contract is a } \\
\text { separate } \\
\text { agreement } \\
\text { between } \\
\text { customer and } \\
\text { developer }\end{array}$ & $\begin{array}{c}\text { Before November } \\
1,2019, \\
\text { capped at } 200 \\
\text { MW }\end{array}$ & $\begin{array}{l}\text { Not specified, } \\
\text { determined by } \\
\text { contract with } \\
\text { developer }\end{array}$ \\
\hline $\begin{array}{l}\text { NV Energy } \\
\text { (NV) }\end{array}$ & $\begin{array}{l}\text { Certain classes of } \\
\text { large customers }\end{array}$ & $\begin{array}{l}\text { Determined by } \\
\text { final agreement } \\
\text { with supplier }\end{array}$ & At least 2 years & $\begin{array}{l}\text { Retired against } \\
\text { customers' } \\
\text { share of } \\
\text { renewable } \\
\text { portfolio } \\
\text { standard } \\
\text { obligation; then, } \\
\text { RECs are } \\
\text { retired on } \\
\text { customer's } \\
\text { behalf }\end{array}$ & $\begin{array}{c}\text { No specific } \\
\text { enrollment } \\
\text { period; } \\
\text { annual } \\
\text { subscription limit: } \\
\text { 250,000 MWh for } \\
\text { northern Nevada, } \\
250,000 \text { MWh for } \\
\text { southern Nevada }\end{array}$ & $\begin{array}{l}\text { Not specified, } \\
\text { determined by } \\
\text { contract with } \\
\text { developer }\end{array}$ \\
\hline $\begin{array}{l}\text { Omaha Public } \\
\text { Power } \\
\text { District (NE) }\end{array}$ & $\begin{array}{l}\text { Certain large- } \\
\text { power and high- } \\
\text { voltage customers }\end{array}$ & $\begin{array}{l}\text { Depends on } \\
\text { market rates } \\
\text { and the } \\
\text { separate } \\
\text { renewable } \\
\text { contract cost }\end{array}$ & $\begin{array}{l}\text { Minimum of } 12 \\
\text { consecutive } \\
\text { months or the } \\
\text { length of the } \\
\text { utility's signed } \\
\text { contract }\end{array}$ & $\begin{array}{c}\text { REC } \\
\text { management } \\
\text { arranged with } \\
\text { developer }\end{array}$ & $\begin{array}{c}\text { No specific } \\
\text { enrollment period } \\
\text { or program limit }\end{array}$ & $\begin{array}{l}\text { Not specified, } \\
\text { determined by } \\
\text { contract with } \\
\text { developer }\end{array}$ \\
\hline $\begin{array}{l}\text { Puget Sound } \\
\text { Energy (WA) }\end{array}$ & $\begin{array}{l}\text { Commercial } \\
\text { customers using } \\
\text { over } 10,000 \\
\text { MWh/year; and } \\
\text { government } \\
\text { facilities }\end{array}$ & $\begin{array}{l}\text { Premium } \\
\text { currently; future } \\
\text { net cost will } \\
\text { depend on } \\
\text { credit escalation }\end{array}$ & $\begin{array}{c}10-, 15-, \text { and } \\
20 \text {-year options }\end{array}$ & $\begin{array}{l}\text { RECs owned } \\
\text { by/retired for } \\
\text { customer }\end{array}$ & $\begin{array}{l}\text { Annual open } \\
\text { season May 1- } \\
\text { July } 31\end{array}$ & $\begin{array}{l}\text { Penalty for } \\
\text { early exit }\end{array}$ \\
\hline $\begin{array}{l}\text { Public } \\
\text { Service } \\
\text { Company of } \\
\text { New Mexico } \\
\text { (NM) }\end{array}$ & $\begin{array}{c}\text { Certain classes of } \\
\text { new, large } \\
\text { customers ( } \geq 10 \\
\text { MW) and } \geq 75 \% \\
\text { load factor }\end{array}$ & $\begin{array}{l}\text { Determined by } \\
\text { final agreement } \\
\text { with supplier }\end{array}$ & $\begin{array}{l}\text { Contract must } \\
\text { have the same } \\
\text { length as } \\
\text { contract with } \\
\text { supplier }\end{array}$ & $\begin{array}{l}\text { RECs owned } \\
\text { by/retired for } \\
\text { customer }\end{array}$ & $\begin{array}{c}\text { No specific } \\
\text { enrollment period } \\
\text { or program limits }\end{array}$ & $\begin{array}{c}\text { Early } \\
\text { termination fee } \\
\text { included }\end{array}$ \\
\hline $\begin{array}{l}\text { Rocky } \\
\text { Mountain } \\
\text { Power (UT) }\end{array}$ & $\begin{array}{l}\text { Certain classes of } \\
\text { large customers } \\
\text { able to purchase } \\
\geq 2 \mathrm{MW}\end{array}$ & $\begin{array}{l}\text { Determined by } \\
\text { final agreement } \\
\text { with supplier }\end{array}$ & $\begin{array}{c}\text { Contract } \\
\text { specific; must } \\
\text { be same length } \\
\text { of utility contract } \\
\text { with supplier }\end{array}$ & $\begin{array}{l}\text { RECs owned } \\
\text { by/retired for } \\
\text { customer }\end{array}$ & $\begin{array}{l}\text { No specific } \\
\text { enrollment } \\
\text { period; } \\
\text { capped at } 300 \\
\text { MW }\end{array}$ & $\begin{array}{l}\text { Not specified, } \\
\text { determined by } \\
\text { contract with } \\
\text { developer }\end{array}$ \\
\hline $\begin{array}{l}\text { Xcel Energy } \\
\text { (MN) }\end{array}$ & $\begin{array}{l}\text { Any customer that } \\
\text { pays fuel clause } \\
\text { charge }\end{array}$ & $\begin{array}{l}\text { Determined by } \\
\text { length of } \\
\text { contract and } \\
\text { fluctuation in } \\
\text { fuel clause } \\
\text { charge }\end{array}$ & $\begin{array}{l}\text { Month-to- } \\
\text { month, } 5 \text { years, } \\
\text { and } 10 \text { years }\end{array}$ & $\begin{array}{l}\text { RECs owned } \\
\text { by/retired for } \\
\text { customer }\end{array}$ & $\begin{array}{c}\text { No specific } \\
\text { enrollment } \\
\text { period; capped at } \\
50 \mathrm{MW} \text { of wind } \\
\text { and } 25 \mathrm{MW} \text { of } \\
\text { solar; available } \\
\text { for } 10 \text { years }\end{array}$ & $\begin{array}{l}\text { \$10/MWh } \\
\text { penalty } \\
\text { multiplied by } \\
\text { last } 12 \text { months } \\
\text { of usage }\end{array}$ \\
\hline $\begin{array}{l}\text { Xcel Energy } \\
\text { (CO) }\end{array}$ & $\begin{array}{l}\text { Certain classes of } \\
\text { large customers }\end{array}$ & $\begin{array}{l}\text { Depends on } \\
\text { market rates }\end{array}$ & $\begin{array}{l}\text { Month-to- } \\
\text { month, } 5 \text { years, } \\
\text { and } 10 \text { years }\end{array}$ & $\begin{array}{l}\text { RECs owned } \\
\text { by/retired for } \\
\text { customer }\end{array}$ & $\begin{array}{c}\text { No specific } \\
\text { enrollment } \\
\text { period; capped at } \\
50 \mathrm{MW}\end{array}$ & $\begin{array}{l}\text { Fixed fees for } \\
\text { customers on a } \\
\text { 5- or 10-year } \\
\text { contract }\end{array}$ \\
\hline
\end{tabular}

a Content based upon Dominion Energy Virginia's Schedule MBR tariff.

b Content based upon Rocky Mountain Power's Service From Renewable Energy Facilities, Schedule 32 tariff.

Adapted from Tawney et al. (2017) and Heeter (2017). 
As of June 2017, corporations and utilities have signed agreements for 900 MW of renewable capacity via green tariff programs (Figure 12). To date, $730 \mathrm{MW}$ of this capacity has been procured from solar projects; and Apple, Amazon, and Switch account for the majority of the capacity (World Resources Institute 2017). According to the World Resources Institute (2017), corporations and utilities are in negotiations to add $465 \mathrm{MW}$ of capacity.

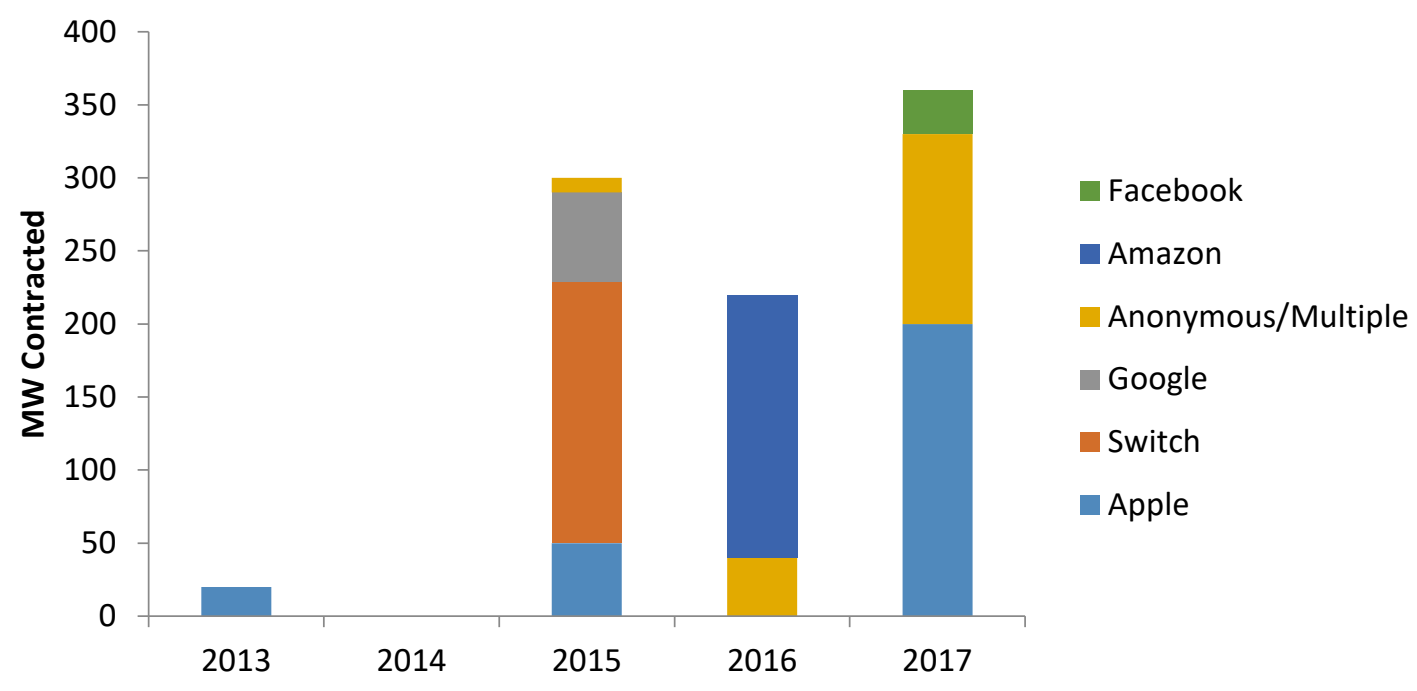

Figure 12. Corporate renewable energy contracts with regulated utilities by year.

Source: World Resources Institute (2017)

It is more difficult to track bilateral agreements because the terms and contracted capacity are not always publically disclosed. Of the 10 projects identified for this report, Google accounts for 4 of them (Table 5). Of those projects, Google disclosed the capacity for 2, totaling $455 \mathrm{MW}$ of wind. Although wind projects are dominant in these bilateral agreements, some corporations have contracted for solar (Walmart) and biomass (Procter \& Gamble). 
Table 5. Bilateral Agreements for Renewable Energy by State, Company, and Utility

\begin{tabular}{|c|c|c|c|c|c|}
\hline State & Corporation & Utility & Project & Capacity & $\begin{array}{l}\text { Estimated } \\
\text { Contract } \\
\text { Year }\end{array}$ \\
\hline Alabama & Google & $\begin{array}{l}\text { Tennessee } \\
\text { Valley Authority }\end{array}$ & In development & Unknown & NA \\
\hline Alabama $^{a}$ & Walmart & Alabama Power & $\begin{array}{l}\text { Lafayette Solar } \\
\text { Project }\end{array}$ & $72 \mathrm{MW}$ & 2016 \\
\hline Arizona & 10 & $\begin{array}{l}\text { Arizona Public } \\
\text { Service }\end{array}$ & $\begin{array}{l}\text { Mix of } 95 \% \text { wind } \\
\text { and } 5 \% \text { solar }\end{array}$ & Unknown & Unknown \\
\hline Arizona & EBay & $\begin{array}{l}\text { Arizona Public } \\
\text { Service }\end{array}$ & Not disclosed & Unknown & Unknown \\
\hline Georgia & Procter \& Gamble & Georgia Power & $\begin{array}{l}\text { Constellation } \\
\text { Albany Biomass } \\
\text { Plant }\end{array}$ & $50 \mathrm{MW}$ & 2015 \\
\hline lowa & Facebook & $\begin{array}{l}\text { MidAmerican } \\
\text { Energy }\end{array}$ & $\begin{array}{l}\text { Wellsburg Wind } \\
\text { Project }\end{array}$ & $138 \mathrm{MW}$ & 2013 \\
\hline lowa & Google & $\begin{array}{l}\text { MidAmerican } \\
\text { Energy }\end{array}$ & Wind VIII Project & $407 \mathrm{MW}$ & 2014 \\
\hline Nebraska & Becton Dickinson & $\begin{array}{l}\text { Nebraska Public } \\
\text { Power District }\end{array}$ & $\begin{array}{l}\text { Steel City Project } \\
\text { (wind) }\end{array}$ & $30 \mathrm{MW}$ & 2013 \\
\hline Oklahoma & Google & $\begin{array}{l}\text { Grand River Dam } \\
\text { Authority }\end{array}$ & $\begin{array}{l}\text { Canadian Hills } \\
\text { Wind }\end{array}$ & $48 \mathrm{MW}$ & 2012 \\
\hline Tennessee & Google & $\begin{array}{l}\text { Tennessee } \\
\text { Valley Authority }\end{array}$ & In development & Unknown & NA \\
\hline
\end{tabular}

a Though at current Walmart is the only subscriber to the Lafayette solar project, other corporate customers could subscribe to unused capacity at the location.

Sources: Alberty and Gustafson (2012); Arizona Corporation Commission (2015); BD (2013); Biemer and Popyk (2015); Gammons (2015); MidAmerican Energy Company (2014); Randazzo (2015); Randazzo (2016); Smith (2013); State of Alabama Public Service Commission (2016); Ward (2015)

\subsection{Case Study: Alabama Power Renewable Procurement Program}

While most bilateral agreements with utilities have been for wind resources, Alabama Power and Walmart signed a contract for solar in 2016. While Walmart has been the only customer, to date, to use this option, it is open to other customers to execute a "subscription" with their own bilateral contract with Alabama Power.

This program offers a potentially replicable approach for other regulated utilities that do not want to develop a full green tariff program. Here, the Alabama Public Service Commission (PSC) granted Alabama Power the authority to pursue up to $500 \mathrm{MW}$ of renewable energy for interested customers via the utility's integrated resource planning process. The utility must bring each individual project to the PSC for approval. This case study discusses the history of this program and its current status. 
To offer corporate customers access to renewable energy, Alabama Power submitted a Petition for a Certificate of Convenience and Necessity to the Alabama PSC on June 25, 2015. The utility's petition requested the authority to pursue up to $500 \mathrm{MW}$ of renewable energy composed of individual projects no larger than 80 MW through 2021 (McCrary 2015). The principle reasons for the request were to serve military renewable procurement requirements and because the utility is "now receiving inquiries from existing and potential customers as to whether the Company can facilitate those customers' compliance with internal corporate goals relating to renewable energy" (McCrary 2015, p. 3). Alabama Power proposed two criteria to evaluate projects for procurement under this program 1) the project is a qualifying renewable project and 2) the project provides an economic benefit. This economic benefit can be demonstrated via load growth or retention, compliance with governmental mandates, and customer-specific contributions to the project (McCrary 2015).

The PSC approved Alabama Power's proposal in September 2015 (State of Alabama Public Service Commission 2015a), which allowed Alabama Power to conduct a request for proposals for renewable projects and bring those individual projects back to the PSC. The program was also structured such that multiple subscribers (i.e., corporations) could participate in one larger project to leverage economies of scale. Shortly after program approval, Alabama Power submitted two U.S. Army projects to the PSC: the Anniston Army Depot and Fort Rucker solar projects (State of Alabama Public Service Commission 2015b). Each project included 10.6 MW of solar to operate during a 29-year term. Alabama Power asserted that the projects offered economic benefits to all customers, primarily through load retention of the military installations. To ensure that the projects provided benefits to all ratepayers, the PSC compared the project costs to future utility power forecast costs, potential environmental regulations, and the direct and indirect benefits of retaining the military installations. The PSC determined that the projects were in line with the public interest and approved the projects on December 14, 2015, primarily because of the importance to local economies of retaining the military installations (State of Alabama Public Service Commission 2015a).

The PSC then approved Alabama Power's LaFayette solar project on June 9, 2016, which was in partnership with Walmart and the utility's first corporate-driven project (State of Alabama Public Service Commission 2016). Alabama Power proposed the 72-MW solar project under a 28 -year PPA agreement. Walmart agreed to a 15-year participation contract with Alabama Power, wherein Walmart will contribute financial support to enhance the PPA's positive economic benefits to all customers. In exchange, Alabama Power will retire the projects' corresponding RECs that are associated with Walmart's subscription. Walmart has the option to renew the partnership after the term of the contract. The PSC determined that the project offered economic benefits to all utility customers based on an analysis of avoided energy and capacity savings as well as the confidential contributions from Walmart under the participation contract. Going forward, Alabama Power expects to use a similar partnership model for other interested corporations to subscribe to unused capacity at LaFayette and future projects (State of Alabama Public Service Commission 2016).

\subsection{Utility Partnership Outlook}

To date, utilities among 17 states have employed green tariff programs or bilateral agreements to offer corporate customers access to long-term agreements for renewable energy. With $900 \mathrm{MW}$ 
of existing capacity and an additional $465 \mathrm{MW}$ in the pipeline, corporations are beginning to take advantage of these green tariff programs in particular.

Corporations are interested in these options in part because they offer long-term renewable energy at a set price without requiring them to build out energy market expertise; however, not all corporations have access to utility-managed programs. Of the 29 fully regulated states, only 17 have utilities that have programs in place or experience working with corporations to procure renewable energy. Nevertheless, in recent years, utilities have been adopting these programs more frequently, suggesting that corporate access to renewable energy in regulated markets is likely to expand.

Despite the proliferation of these programs, some corporations are concerned about the costs of participation. Some argue that these programs have higher costs coupled with exposure to market risk. These issues can serve as barriers that might temper corporate interest. At the same time, utilities continue to learn from the implementation of green tariff programs, and it is possible that innovations and cost savings will materialize that can make green tariff programs more attractive. 


\section{FERC Authorized Wholesale Seller of Electricity}

This section explores how becoming a wholesale seller works, followed by a discussion of the benefits and challenges of this pathway. The section then discusses the status of licensed wholesale sellers, with a case study on Google Energy LLC. It concludes with a discussion of the outlook for corporate interest in becoming a wholesale seller.

\subsection{How Companies Become a Wholesale Seller}

With FERC approval, companies can sell electricity into wholesale markets. Companies with approval can therefore take title to the electricity produced by their owned or contracted renewable energy generators; this is unlike the other procurement pathways presented in this paper, which typically rely on utilities, competitive suppliers, or renewable generators to be owning the power. For companies that have significant energy expenses, becoming a federallyregulated wholesale electricity supplier can allow them to better manage electricity costs as well as sell renewable energy that they own into wholesale markets. For example, Walmart's subsidiary, Texas Retail Energy, supplies Walmart facilities in Texas, and was expected to save the company \$15 million annually (Thomas 2007) compared to procuring electricity from a different supplier.

Becoming a licensed wholesale seller of electricity is typically done for the purpose of selling conventional generation; however, in recent years an increasing number of individual renewable generators and renewable energy-focused suppliers have been approved. ${ }^{16}$

A company interested in being approved must submit an application to FERC that describes the company and demonstrates that the company meets FERC's licensing requirements. To do this, companies need to document to FERC that they do not have market power in the regions in which they operate. FERC has established tests for market power: The test for horizontal market power examines whether the seller owns or controls generation in the relevant balancing authority area or regional transmission organization/independent system operator where the seller's generation is located. FERC uses two screens to assess horizontal market power: the pivotal supplier analysis and the market share:

- The pivotal supplier analysis examines how much uncommitted capacity owned or controlled by the seller compares to the net uncommitted capacity in the relevant market (balancing authority area or regional transmission organization/independent system operator).

- The market share analysis examines the seller's share of uncommitted capacity on a seasonal basis in the relevant market.

In the case of Google Energy, FERC found that because neither Google Energy, Google, nor any affiliates own or control wholesale electric generation facilities, they pass the horizontal market power test (FERC 2010).

\footnotetext{
${ }^{16}$ Relatedly, the University of California became an electric service provider in California, which enabled it to sign two PPAs for solar energy ( $80 \mathrm{MW}$ total) and sell the electricity to a number of its campuses under direct access rules (University of California 2014).
} 
The test for vertical market power includes examining whether the seller could influence the transmission facilities in the region. Google Energy stated that it does not (and its affiliates do not) own or control any transmission facilities nor have they erected any market barriers. Because Google Energy passed both the horizontal and vertical market tests, FERC accepted their application to become a licensed wholesale electricity seller.

\subsection{Benefits and Challenges of Wholesale Market Participation}

When Apple received FERC approval in 2016, many articles speculated that Apple would begin operating as a retail electricity supplier. In fact, no such product has emerged, either from Apple or any of the other corporate customers receiving FERC approval. Instead, corporations seeking to be licensed as wholesale suppliers are looking for the ability to better manage their energy projects.

Some companies are looking for more control over electricity costs. Chris Hendrix, the general manager of Texas Retail Energy, noted the benefits of operating in the wholesale marketplace: "Our direct involvement at the wholesale level gives us better visibility of the energy marketplace, makes market pricing transparent, and allows us to manage our load much like an investment portfolio with a variety of suppliers, structures, and terms" (Hendrix 2006).

Other companies see a benefit to creating unique renewable purchasing options. This method enabled Google's renewable PPAs, although to date Google Energy has not used the model for solar procurement. Google signs long-term PPAs for renewable energy, then sells the energy back to the grid while keeping the RECs from the generation. Google (2016) noted that this strategy helps them reach their renewable goals while "gaining certainty in our financial planning." Apple is selling wholesale energy from a 50-MW solar project in Arizona to Salt River Project, then keeping the RECs from the project to meet its sustainability goals (Salt River Project 2016).

The challenges of this model revolve around the complexity of implementing it and the risk taken by the company. Being allowed to benefit from wholesale market sales also requires investment in either building an energy team or hiring out these capabilities. Many large corporations do not want to be that involved with energy purchases. Energy is not their core business, and they would rather focus on areas where they believe they have a competitive advantage. The larger challenge, however, is likely that corporations might not want to take on the level of market risk involved with being a wholesale seller. This is because wholesale sellers are subject to the price volatility of the energy market into which they are selling. Instead, companies tend to prefer purchasing the energy and RECs through a long-term PPA.

\subsection{Market Status of Licensed Wholesale Sellers}

Although FERC approved more than 2,000 organizations to use wholesale market-based rates, those organizations are typically generating units or companies not associated with a corporate end user such as Google or Apple. This mechanism has been in place since 1988, though only recently have corporations been using the structure to facilitate renewable energy procurement (FERC 2017). A few companies that have been approved include: 
- Alcoa Power Marketing, Inc., a subsidiary of Alcoa, the aluminum manufacturer (2002)

- Texas Retail Energy, a subsidiary of Walmart (2005); it was operating in the Electric Reliability Council of Texas in 2004 (Hendrix 2006).

- Safeway Inc., the grocery chain (2006)

- Google Energy (2010)

- Apple Energy (2016).

Overall, it is more common for a renewable energy project to be approved to sell rather than a company seeking license to sell (FERC 2017).

\subsection{Case Study: Google Energy's Market-Based Rate Authority}

In 2009, Google was looking for ways to source renewable power for its operations in the United States. At the time, utility green tariffs were not available. Google was looking to source renewables from a new facility and to ensure that it was able to make renewable claims by keeping the RECs from the renewable facility.

Google found a solution by forming a subsidiary, Google Energy, LLC, and seeking FERC authorization to buy and sell in wholesale electricity markets. Receiving this approval allowed Google to sign a PPA in 2010 for 114 MW of wind in Iowa, then sell that electricity back to the grid while retaining the RECs.

At the time of filing, Google Energy did not own or control any commercial electric generation or transmission in North America. Google did own electricity for use at its own facilities and for emergency backup power; thus, its application process was much shorter than that of Apple's because it did not need to demonstrate how it passed FERC's horizontal and vertical market power tests. Google was required to notify FERC within 30 days after a change occurred of any changes in ownership or control or affiliation with others that own or control generation or transmission.

In more recent filings, Google Energy noted that it owns approximately 33\% of Ivanpah Master Holdings, LLC, which has three large solar assets (126 MW, $133 \mathrm{MW}$, and $133 \mathrm{MW}$ for the Ivanpah I, II, and III projects, respectively). These projects are controlled by investor-owned utilities, which have PPAs for the output of the facilities; but Google Energy was required to disclose them to FERC because of their ownership of the company.

Google Energy also noted in its February 2017 update to FERC that it has six long-term PPAs, all for wind energy, including the $114 \mathrm{MW}$ of wind in Iowa and five projects located in the Southwest Power Pool: Minco Wind II, 100.8 MW; Great Western Wind Energy, 225 MW; Bluestem Wind Energy, 198 MW; Cimarron Bend Wind Project I, 200 MW; and Bethel Wind Farm, 225 MW) (Google Energy 2017).

\subsection{Wholesale Seller Outlook}

Receiving market-based rate authority opens up a lot of opportunity for a corporate customer to manage their electricity costs. Corporate customers that have large electricity demands and interest in developing in-house energy expertise, or contracting for it, could benefit from this 
pathway; however, because most corporate customers are not interested in being involved in the energy business, this pathway is not likely to be pursued broadly. This conclusion is consistent with stakeholders interviewed in this study that were not aware of any pending applications for FERC approval. 


\section{Pathway Comparison and Outlook}

Market innovation is enabling corporate solar procurement, including new purchasing models, declining costs, and increased interest by corporate purchasers. The market drivers for largescale solar photovoltaic are poised to continue in the near term: increased interest by corporate customers in renewable energy procurement, declining solar costs and increasing retail electricity rates, as well as a rush to sign projects that will receive the full $30 \%$ investment tax credit by commencing construction before the end of 2019. A critical question is which pathway offers corporations the best opportunity to leverage these developments and deploy more solar.

Each pathway provides different levels of value to corporate purchasers. In addition, corporations will consider a range of metrics when determining which procurement option is most appropriate for them (Table 6). Each pathway differs in the hedging value it provides, ease of implementation, and availability.

- Hedge value. Corporations interested in procuring solar would prefer the best value proposition available in a given location. This value is driven largely by the scope of the hedging opportunity. In this context, operating as a licensed wholesale electricity supplier might offer the best opportunity, followed by PPAs. In the retail choice and utility green tariff pathways, contracts might be shorter term, and the fixed rate might be influenced by retail supplier and utility participation in the contract.

- Ease of implementation. Corporations are also interested in reducing the administrative costs of their off-site purchases (in term of staffing and knowledge development as well as administrative fees paid to utilities or others). In this regard, utility green tariff programs and retail choice require less internal capacity building and market expertise, but they might come at the expense of paying administrative or other fees.

- Availability. The availability of these options can influence which pathways corporations are able to pursue in a given location. Availability might also influence how corporations might source electricity to serve existing facilities and how they make siting decisions for future facilities. In this context, the licensed wholesale electricity supplier pathway is most attractive because it is available to any corporation across the United States. In comparison, PPAs, retail choice, and utility green tariff programs are more limited in geographic scope. 
Table 6. Comparison of Corporate Utility-Scale Procurement Models

\begin{tabular}{|c|c|c|c|c|}
\hline & $\begin{array}{l}\text { Power Purchase } \\
\text { Agreements }\end{array}$ & Retail Choice & $\begin{array}{l}\text { Utility } \\
\text { Partnerships }\end{array}$ & $\begin{array}{l}\text { Licensed } \\
\text { Wholesale } \\
\text { Electricity Seller }\end{array}$ \\
\hline Availability & $\begin{array}{l}\text { Typically requires } \\
\text { wholesale market } \\
\text { access }\end{array}$ & $\begin{array}{l}\text { Full or partial } \\
\text { access in } 21 \\
\text { states }\end{array}$ & $\begin{array}{l}\text { Certain utility } \\
\text { jurisdictions in } 17 \\
\text { states }\end{array}$ & $\begin{array}{l}\text { Any company that } \\
\text { owns or has } \\
\text { interest in owning } \\
\text { utility-scale } \\
\text { generation }\end{array}$ \\
\hline $\begin{array}{l}\text { Corporate } \\
\text { Access }\end{array}$ & $\begin{array}{l}\text { Large corporate } \\
\text { customers, and } \\
\text { emerging } \\
\text { aggregation } \\
\text { opportunities }\end{array}$ & $\begin{array}{l}\text { All or certain large } \\
\text { corporate } \\
\text { customers, no } \\
\text { aggregation } \\
\text { opportunities }\end{array}$ & $\begin{array}{l}\text { Certain large } \\
\text { corporate } \\
\text { customers and } \\
\text { emerging } \\
\text { aggregation } \\
\text { opportunities }\end{array}$ & $\begin{array}{l}\text { Any company, no } \\
\text { aggregation } \\
\text { opportunities }\end{array}$ \\
\hline $\begin{array}{l}\text { Energy Market } \\
\text { Expertise and } \\
\text { Corporate } \\
\text { Approval } \\
\text { Requirements }\end{array}$ & Medium-high & Medium-low & Low-Low & $\begin{array}{l}\text { Very high-Very } \\
\text { high }\end{array}$ \\
\hline Contract Control & $\begin{array}{l}\text { Corporation } \\
\text { manages the } \\
\text { contract }\end{array}$ & $\begin{array}{l}\text { Corporation } \\
\text { manages the } \\
\text { contract }\end{array}$ & $\begin{array}{l}\text { Utility (in some } \\
\text { cases with input } \\
\text { from corporation) } \\
\text { manages the } \\
\text { contract }\end{array}$ & $\begin{array}{l}\text { Corporation } \\
\text { manages the } \\
\text { contract }\end{array}$ \\
\hline $\begin{array}{l}\text { Length of } \\
\text { Contract }\end{array}$ & 10-20 years & Negotiable & $\begin{array}{l}\text { Varies by utility } \\
\text { program }\end{array}$ & $\begin{array}{l}\text { Negotiable } \\
\text { (typically longer } \\
\text { term, 10-20 years) }\end{array}$ \\
\hline $\begin{array}{l}\text { Hedging } \\
\text { Opportunity and } \\
\text { Risk Profile }\end{array}$ & $\begin{array}{l}\text { High hedge value, } \\
\text { but subject to } \\
\text { wholesale market } \\
\text { hub or node price } \\
\text { volatility risk }\end{array}$ & $\begin{array}{l}\text { Hedge opportunity } \\
\text { depends on length } \\
\text { of contract and is } \\
\text { subject to retail } \\
\text { market price } \\
\text { volatility risk }\end{array}$ & $\begin{array}{l}\text { Hedge opportunity } \\
\text { depends on length } \\
\text { of contract, credit } \\
\text { structure, and/or } \\
\text { wholesale market } \\
\text { price volatility risk }\end{array}$ & $\begin{array}{l}\text { High hedge value, } \\
\text { but subject to } \\
\text { wholesale market } \\
\text { hub or node price } \\
\text { volatility risk }\end{array}$ \\
\hline $\begin{array}{l}\text { Reliability } \\
\text { requirements }\end{array}$ & $\begin{array}{l}\text { Utility delivers firm, } \\
\text { reliable power }\end{array}$ & $\begin{array}{l}\text { Supplier delivers } \\
\text { firm, reliable power }\end{array}$ & $\begin{array}{l}\text { Utility delivers firm, } \\
\text { reliable power }\end{array}$ & $\begin{array}{l}\text { Corporation might } \\
\text { need to establish } \\
\text { contracts to secure } \\
\text { firm, reliable power }\end{array}$ \\
\hline Title to Power & Supplier & Supplier & Utility & Corporation \\
\hline
\end{tabular}

\subsection{Expanding Off-Site Solar Procurement Options}

For the corporate solar procurement market to grow, more purchasing options need to be available at decreased price points for corporate buyers. Corporate buyers need access not only to a purchasing option but one that will be feasible for them to sell to senior executives. There are a variety of opportunities to expand corporate access to each of the four pathways as well as make them more attractive to prospective companies. These opportunities were generated from the interviewees who participated in this study and are summarized for each pathway in turn. 


\subsubsection{PPAs}

To enable PPAs in new markets, state policymakers could open electricity markets to wholesale access. Because financial PPAs require renewable projects to sell into a wholesale market, projects in states such as Arizona and New Mexico cannot move forward under a financial PPA.

Additional work is also needed to ensure that PPAs are viable options for smaller corporate purchasers. To date, PPAs have been dominated by information and communication technology companies that have large, centralized loads (O'Shaughnessy et al. 2016; Miller et al. 2015), but many smaller corporate purchasers are beginning to take interest in the option. Aggregation of smaller loads is time-consuming and to date has been done only in limited numbers; however, as corporate interest increases among smaller purchasers, creating PPA aggregation models would allow greater numbers of companies, and megawatts, to be signed.

To further reduce PPA prices, more standardization of contracts is needed as well as decreased customer acquisition times. Currently, corporate solar contracts are negotiated on the basis of each individual company, which is time-consuming and adds costs to the project. If corporations and solar developers were to use a more standardized PPA, these costs could come down. Standardizing contracts could also create a secondary market for financing projects. In addition to standardizing contracts, decreasing the time to acquire a corporate off-taker could improve project economics. Developers have noted that corporate customers often require a lot of education before signing deals, particularly when compared to a utility off-taker. Developers also need a sense of where potential corporate off-take is located, to site projects accordingly; this is especially an issue for large utility-scale solar projects, which take more time to site and construct than on-site solar projects.

\subsubsection{Retail Choice}

State policymakers could also open markets to retail choice, either for some or all retail customers. To date, 21 states allow at least some corporate customers to purchase electricity from their choice of suppliers, with 8 of those states having only partial retail choice. Although there is movement in Nevada and Washington to allow more retail choice (either for the market as a whole, as in Nevada; or for specific customers, in the case of Microsoft in Washington), the retail choice cap in Michigan was recently maintained. Because of the complexities in restructuring retail electricity markets, there will likely be little movement in expanding retail choice in the short term.

If state policymakers are interested in creating opt-out provisions such as those in Nevada, one of the more contentious issues to be aware of is the process of assessing exit fees. Exit fees are designed to keep existing ratepayers whole for any costs incurred by the corporation leaving the utility. In Nevada, exit fees are determined at the level of the PUCN.

\subsubsection{Utility Partnerships}

Utilities have primarily been adopting green tariffs voluntarily, but state policymakers could direct utilities under their purview to create and provide a green tariff. Michigan's Public Act 342 (2016) required electricity providers to offer a voluntary green pricing program. Although the act did not specify that the program needed to be a green tariff program, Consumers Energy proposed a green tariff to fulfill their obligation under the statute. To date, only 7 utilities have 
green tariffs with customers, and an additional 7 utilities have participated in bilateral agreements with corporate off-takers; however, there is increased interest by utilities in developing new arrangements. These options can take time to develop, with public utilities commission approval needed for both the tariff and individual contract.

To increase the use of green tariffs, utilities, corporate off-takers, and public utility commissions could consider creating green tariffs and bilateral contracts that provide value to both the utility and the subscribing customer. Corporate customers want to ensure that their participation is not laden with heavy administrative costs and that the full value of the price hedge is passed through in the green tariff or bilateral contract. At the same time, utilities want to ensure that their transmission and distribution costs are compensated.

\subsubsection{Wholesale Electricity Supplier}

Although becoming a wholesale electricity supplier offers the greatest control over corporate electricity use, to date it is a complex process in which few corporate customers have taken interest. Corporate customers that have large electricity loads might be interested in learning from the experience of those that have undertaken the option to better evaluate whether it would make sense for them.

\subsection{Future Outlook Summary}

Existing purchasing options will improve access and viable purchasing options for corporate customers to buy off-site renewable energy. However, for solar to play a larger role in corporate purchasing, states and utilities should consider working with stakeholders to develop purchasing options in areas where solar is most cost-competitive. Many interviewees noted that corporate purchasers have little preference for either solar or wind; rather, they are looking only at the availability of renewable projects at lowest cost. Although solar has dominated corporate purchasing in some areas of the country, in other areas purchasing is currently dominated by wind. Opening options in areas of the country where solar is most cost-competitive could make it a preferred option for corporate customers. Figure 13 shows the levelized cost of energy (LCOE) of utility-scale solar using a one axis tracker and corporate procurement of renewable energy, by state. 


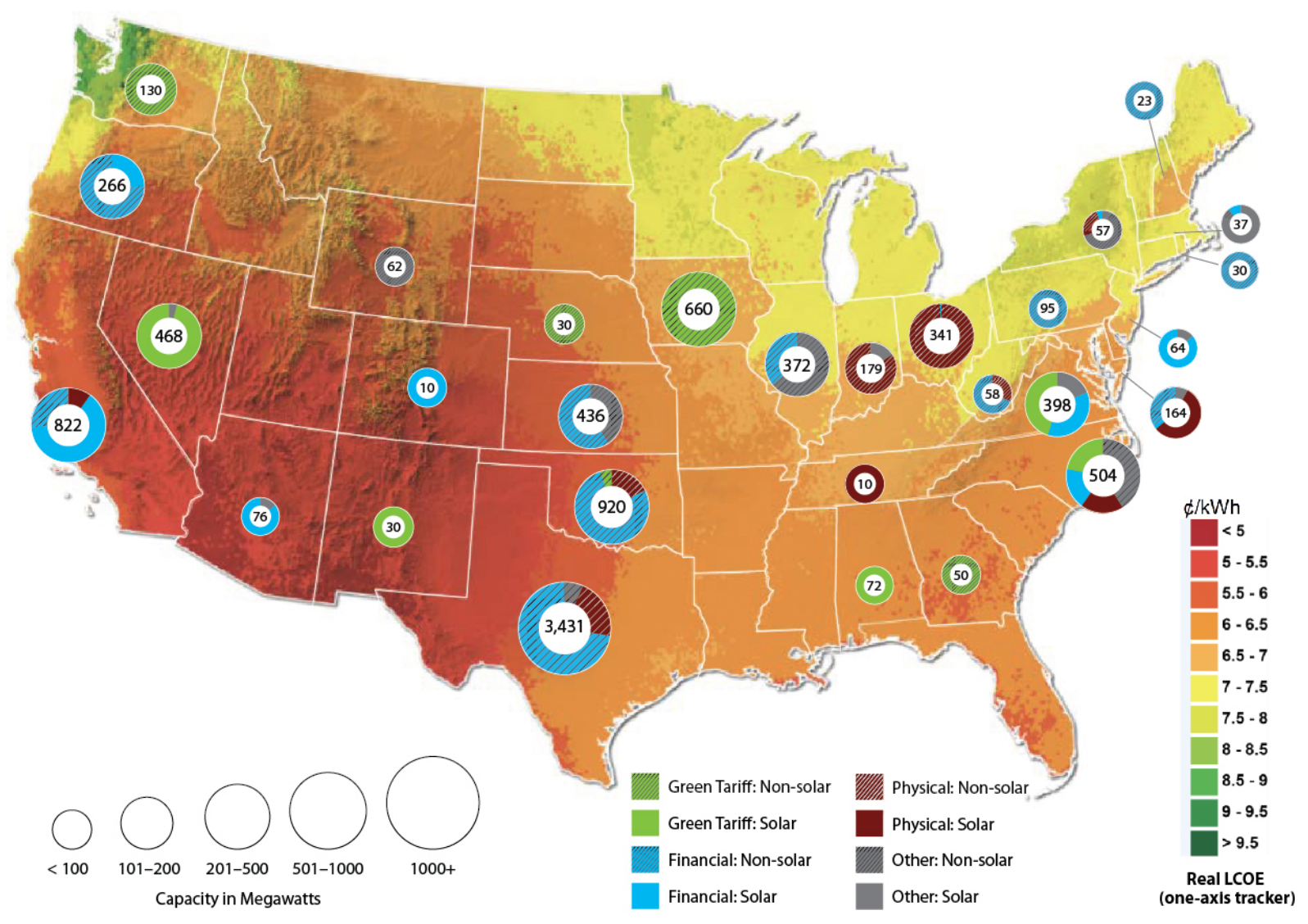

Figure 13. Corporate RE purchasing (MW) by state and utility-scale solar levelized cost of energy (LCOE)

LCOE source: Fu et al. (2016); capacity data from NREL and BNEF (2017)

Of the states with the greatest solar potential (on an LCOE basis), California and Nevada have seen the greatest MW of corporate PV purchasing, through financial PPAs (California) and green tariffs (Nevada), but purchasing options are just emerging or do not exist in other areas of the country with strong solar potential. 


\section{References}

2001 Statutes of Nevada, Page 3226. Chapter 604, AB 661.

https://www.leg.state.nv.us/Statutes/71st/Stats200121.html\#CHz604 zABz661. State of Nevada.

2002 Statutes of California, Page 92. Chapter 838, Assembly Bill No. 117.

http://www.leginfo.ca.gov/pub/01-02/bill/asm/ab_0101-

0150/ab_117_bill_20020924_chaptered.pdf. State of California.

A Better City. 2017. "Innovation through Aggregation: A Case Study of Partnership to Purchase Renewable Energy." http://www.abettercity.org/docsnew/Innovation_Through_Aggregation.pdf.

ACORE. 2016. Corporate Renewable Energy Procurement Industry Insights (Technical Report). Washington, D.C. http://www.acore.org/publications-category/5972-corporate-renewableenergy-procurement-industry-insights.

Alberty, Justin, and Katy Gustafson. 2012. "Google and GRDA Announce Renewable Energy Agreement in Oklahoma." September 26. http://www.grda.com/google-and-grda-announcerenewable-energy-agreement-in-oklahoma/.

Arizona Corporation Commission. 2015. "Docket No. E-01345A-15-0117: In the Matter of the Application of Arizona Public Service Company for Approval of Electric Service Contracts with eBay, Inc.” http://images.edocket.azcc.gov/docketpdf/0000160605.pdf.

Associated Press. 2016. "Energy Choice Initiative Passes in Nevada." Reno-Gazette-Journal. http://www.rgj.com/story/news/politics/2016/11/09/energy-choice-initiative-passesnevada/93528566/.

BD. 2013. "New Collaboration with Industrial Customer Expands NPPD's Renewable Energy Portfolio."

http://www1.bd.com/contentmanager/b article.asp?Item ID=27357\&ContentType ID=1\&Busin $\underline{\text { essCode }=20001 \& \mathrm{~d}=\& \mathrm{~s}=\text { press } \& \mathrm{dTitle}=\text { Press } \& \mathrm{dc}=\text { Worldwide } \& d c T i t l e=\text { Worldwide. }}$.

Biemer, Kelly, and Lisa Popyk. 2015. "Procter \& Gamble and Constellation Announce One of Nation's Largest Biomass Renewable Energy Plants." February 12. http://news.pg.com/pressrelease/pg-corporate-announcements/procter-gamble-and-constellation-announce-one-nationslarge.

BNEF (Bloomberg New Energy Finance). 2017. "U.S. Corporate PPA project database." September.

Bolinger, Mark, and Joachim Seel. 2016. Utility-Scale Solar 2015: An Empirical Analysis of Project Cost, Performance, and Pricing Trends in the United States (Technical Report LBNL1006037). Berkeley, CA: Lawrence Berkeley National Laboratory. https://emp.lbl.gov/sites/all/files/lbnl-1006037 report.pdf. 
California Public Utilities Commission. 2016. "Supplemental Direct Access Implementation Activities Report: Statewide Summary."

http://www.cpuc.ca.gov/WorkArea/DownloadAsset.aspx?id=11569.

California Public Utilities Commission. N.d. "Statewide Direct Access Load \%.” Direct Access Implementation Activity Reports.

http://www.cpuc.ca.gov/WorkArea/DownloadAsset.aspx?id=6442451798. Also available here: http://www.cpuc.ca.gov/General.aspx?id=6598.

Catasein, Jay. 2015. “A New Way for Companies to Go Green.” Renewable Power Direct Blog, February 27. http://renewablepowerdirect.com/a-new-way-for-companies-to-go-green/.

Chadbourne. 2016. "Negotiating a Corporate PPA." https://www.chadbourne.com/negotiatingcorporate-PPA-project-finance-october-2016.

Chandler, David L. 2016. "MIT to Neutralize 17 Percent of Carbon Emissions through Purchase of Solar Energy." MIT News, October 19. http://news.mit.edu/2016/mit-neutralize-17-percentcarbon-emissions-through-purchase-solar-energy-1019. Accessed June 2, 2017.

Commonwealth of Virginia State Corporation Commission. 2017. "Energy Regulation in Virgina." http://law.lis.virginia.gov/vacode/title56/chapter23/section56-577/.

DLA Piper. 2016. 2016: The Year of PPAs and the Corporate Green Agenda (Technical Report). Washington, D.C.

https://www.dlapiper.com/ /media/Files/Insights/Publications/2016/06/PPA_Paper_Energy_201 6 Jul.pdf.

Edison Electric Institute, World Resource Institute, and World Wildlife Fund. N.d. Creating Renewable Energy Opportunities: Utility-Corporate Buyer Collaborative Forum Strategic Dialogue (Technical Report). Washington, D.C.

http://www.eei.org/about/affiliates/nationalkeyaccounts/tools-and-resources/Documents/UtilityCorporate\%20Buyer\%20Collaborative\%20Forum\%20-\%20Strategic\%20Insights.pdf.

Edwards, Devon, Dan Mitler, Amy O’Meara, Bryn Baker, Joshua Kaplan, Susanne Fratzscher, and Marty Spitzer. 2016. Corporate Renewable Energy Procurement: A Snapshot of Key Trends, Strategies and Practices in 2016 (Technical Report). Washington, D.C.: Corporate Eco Forum and World Wildlife Fund. http://buyersprinciples.org/wp-content/uploads/CEF-WWF-2016Corporate-RE-Procurement FINAL.pdf.

FERC. 2010. "Docket Nos. ER10-468-000 and ER10-468-001: Order Granting Market-Based Rate Authorization." February 18. https://www.ferc.gov/whats-new/comm-meet/2010/021810/e18.pdf.

FERC. 2017. "Market-Based Rates Contact List." Last modified May 31, 2017." https://www.ferc.gov/industries/electric/gen-info/mbr/mbr-contact.xlsx. 
Ran Fu, Donald Chung, Travis Lowder, David Feldman, Kristen Ardani, Robert Margolis. 2016. U.S. Solar Photovoltaic System Cost Benchmark: Q1 2016. NREL/TP-6A20-66532. http://www.nrel.gov/docs/fy16osti/66532.pdf.

Gammons, P. 2015. "A Power Plant for the Internet: Our Newest Data Center in Alabama." Google: Official Blog, June 24. https://googleblog.blogspot.com/2015/06/a-power-plant-forinternet-our-newest.html.

Google Energy. 2017. "Google Energy Change in Status February 2017.”

https:/elibrary.ferc.gov/idmws/common/opennat.asp?fileID=14504149.

Google. 2016. Environmental Report (Technical Report). Mountain View, CA.

https://abc.xyz/investor/pdf/google-2016-environmental-report.pdf.

Heeter, Jenny. 2017. "Utility Green Tariff Programs: Considerations for Federal Agencies" (NREL/PR-6A20-68179). Presented via webinar, Golden, Colorado, May 4.

http://www.nrel.gov/docs/fy17osti/68179.pdf.

Hendrix, C. 2006. "Wal-Mart Masters Energy Markets.” Energy Magazine September/October. http://energycentral.fileburst.com/EnergyBizOnline/2006-5-sep-oct/Legal Eagle Wal Mart.pdf.

Honeyman, Cory, Austin Perea, Shayle Kann, MJ Shiano, Jade Jones, Colin Smith, Benjamin Gallagher, Scott Moskowitz, Allison Mond, Shawn Rumery, Aaron Holm, Katie O'Brien, and Justin Baca. 2016. U.S. Solar Market Insight Full Report Q4 2016. Washington, D.C: GTM Research and Solar Energy Industries Association. http://www.seia.org/research-resources/solarmarket-insight-report-2016-q4.

Miller, John, Lori Bird, Jenny Heeter, and Bethany Gorham. 2015. Renewable Electricity Use by the U.S. Information and Communication Technology (ICT) Industry (Technical Report NREL/TP-6A20-64011). Golden, CO: National Renewable Energy Laboratory. http://www.nrel.gov/docs/fy15osti/64011.pdf.

Litvak, Nicole. 2016. U.S. Commercial Solar Landscape 2016-2020 (Technical Report). GTM Research. https://www.greentechmedia.com/research/report/us-commercial-solar-landscape2016-2020.

McCrary, Dan. 2015. "Petition for a Certificate of Convenience and Necessity." https://www.pscpublicaccess.alabama.gov/pscpublicaccess/ViewFile.aspx?Id=c270983a-40034be3-8947-02ffd81e5e 58.

Michigan Public Service Commission. N.d. "Electric Choice 10\% Cap Data." http://www.dleg.state.mi.us/mpsc/electric/restruct/faq/cap data.html.

Microsoft News Center. 2017. Microsoft and Puget Sound Energy receive approval for energy purchasing agreement (press release). https://news.microsoft.com/2017/07/13/microsoft-pugetsound-energy-receive-approval-energy-purchasing-agreement/\#WE1rq8DDkCc7Xsmh.97. 
MidAmerican Energy Company. 2014. "Google and MidAmerican Energy Company Announce Renewable Energy Agreement.” April 22.

https://www.berkshirehathawayenergyco.com/news/google-and-midamerican-energy-companyannounce-renewable-energy-agreement-in-iowa.

Montana Code Annotated. 2015. "69-8-201. Public utility -- customer electricity supply service options and requirements - exemption.” http://leg.mt.gov/bills/mca/69/8/69-8-201.htm.

Mulkern, Anne C. 2015. "Bill Would Boost Green Power by Expanding Access to Utility Competitors." E\&E News, March 3. http://www.eenews.net/stories/1060014344.

National Renewable Energy Laboratory. 2016. "Energy Analysis: 2016 Annual Technology Baseline." http://www.nrel.gov/analysis/data tech_baseline.html.

O'Shaughnessy, Eric, Chang Liu, and Jenny Heeter. 2016. Status and Trends in the U.S. Voluntary Green Power Market (2015 Data) (Technical Report NREL/TP-6A20-67147). Golden, CO: National Renewable Energy Laboratory. http://www.nrel.gov/docs/fy17osti/67147.pdf.

Oregon Legislative Assembly. 1999. "Senate Bill 1149."

http://www.puc.state.or.us/electric restruc/billsum/sb1149.pdf.

Pacific Power. 2017. “Oregon Direct Access.” https://www.pacificpower.net/directaccess.

Portland General Electric. 2017. "Direct Access Operations."

https://www.portlandgeneral.com/business/power-choices-pricing/market-based-pricing/directaccess-operations.

[PUCN] Public Utilities Commission of Nevada. 2008. "Order."

http://pucweb1.state.nv.us/PDF/AxImages/DOCKETS_2005 THRU_PRESENT/20083/22633.pdf.

PUCN. 2015a. "Procedural Order No. 3."

http://pucweb1.state.nv.us/PDF/AxImages/DOCKETS_2015 THRU_PRESENT/20155/5406.pdf.

PUCN. 2015b. "Order."

http://pucweb1.state.nv.us/PDF/AxImages/DOCKETS_2015 THRU_PRESENT/20155/7908.pdf.

PUCN. 2017. "Order." http://pucweb1.state.nv.us/PDF/AxImages/DOCKETS_2015 THRU_PRESENT/20155/22473.pdf.

Public Utility Commission of Oregon. 2015. "Order." http://apps.puc.state.or.us/orders/2015ords/15-060.pdf. 
Public Utility Commission of Oregon. 2013. "Order."

http://apps.puc.state.or.us/orders/2013ords/13-459.pdf.

Puget Sound Energy. 2016. "Re: Advice No. 2016-28 Electric Tariff Filed-Filed Electronically."

https://www.utc.wa.gov/ layouts/15/CasesPublicWebsite/GetDocument.ashx?docID=7\&year=2 $\underline{016 \& \text { docketNumber }=161123 .}$

Puget Sound Energy. 2017. "Electric Tariffs \& Rules."

https://pse.com/aboutpse/Rates/Pages/Electric-Rate-

Schedules.aspx?Schedule x0020 Type=Rate $\% 20$ and $\% 20$ Adjusting $\% 20$ Schedules

PwC. 2016. Corporate Renewable Energy Procurement Survey Insights (Technical Report). http://www.pwc.com/us/en/corporate-sustainability-climate-change/publications/assets/pwccorporate-renewable-energy-procurement-survey-insights.pdf.

Randazzo, Ryan. 2015. "IO Data Center Offers Renewable-Energy Program." The Arizona Republic, March 5. http://www.azcentral.com/story/money/business/tech/2015/03/05/io-datacenter-offers-renewable-energy-program/24465323/.

Randazzo, Ryan. 2016. "IO Data Center Wants Alternative to APS Power." The Arizona Republic, March 14. http://www.azcentral.com/story/money/business/energy/2016/03/14/io-datacenter-wants-alternative-aps-power/81549716/.

Renewable Choice Energy. 2016. Proactively Managing Risks to Accomplish Your Long-Term Renewable Energy Goals (Technical Report). Boulder, CO.

http://www.renewablechoice.com/wp-content/uploads/2016/03/Updated-PPA-Risks-WhitePaper.pdf

Rothberg, Dan. 2016. "MGM Resorts, Wynn to Stop Purchasing NV Energy Power Saturday." Las Vegas Sun, June 8. https://lasvegassun.com/news/2016/sep/30/mgm-resorts-wynn-stoppurchasing-nv-energy-power/.

Ryan, Cy. 2017. “PUC Approves \$47.5 Million Fee for Caesars to Leave NV Energy.” Las Vegas Sun, March 8. https://lasvegassun.com/news/2017/mar/08/puc-approves-475-million-feefor-caesars-to-leave/.

Salt River Project. 2016. "SRP Launches Major New Renewable Energy Project with Apple." http://www.srpnet.com/newsroom/releases/092116.aspx.

Schmidt, Fred. 2015. "Application of MGM Resorts International to Purchase Energy, Capacity, and/or Ancillary Services from a Provider of New Electric Resources."

http://pucweb1.state.nv.us/PDF/AxImages/DOCKETS_2015 THRU_PRESENT/20155/2370.pdf.

Schmidt, Fred. 2016a. RE: Docket No. 15-05017-Application of MGM Resorts International to Purchase Energy, Capacity, and/or Ancillary Services from a Provider of New Electric Resources. 
http://pucweb1.state.nv.us/PDF/AxImages/DOCKETS_2015 THRU_PRESENT/20155/8593.pdf.

Schmidt, Fred. 2016b. "RE: Docket No. 15-05017-MGM Compliance Filing pursuant to Ordering Paragraph 9 of the Modified Final Order. http://pucweb1.state.nv.us/PDF/AxImages/DOCKETS_2015 THRU_PRESENT/20155/15429.pdf.

Schmidt, Fred. 2016c. “Application Pursuant to NRS 704B of Ceasars Enterprises, LLC to Purchase Energy, Capacity and/or Ancillary Services for Eligible Northern Nevada Meters from a Provider of New Electric Resources." http://pucweb1.state.nv.us/PDF/AxImages/DOCKETS_2015 THRU_PRESENT/201611/17105.pdf.

Schmidt, Fred. 2016d. "Application Pursuant to NRS 704B of Ceasars Enterprises, LLC to Purchase Energy, Capacity and/or Ancillary Services for Eligible Southern Nevada Meters from a Provider of New Electric Resources." http://pucweb1.state.nv.us/PDF/AxImages/DOCKETS_2015 THRU_PRESENT/201611/17109.pdf.

Shiao, MJ., Cory Honeyman, Nicole Litvak, Jade Jones, Scott Moskowitz, Colin Smith, Manan Parikh, Austin Perea, Ben Gallagher, Allison Mond, Benjamin Attia, and Tha Zin. 2017. Q4 2016 Solar Executive Briefing. GTM Research.

SSEA. N.d. SSEA Celebrates 5 Yrs. http://silverstateenergy.org/announcement.php?id=1.

Smith, Patrick. 2013. "Facebook Signs Deal with MidAmerican Wind Energy." WindPower Monthly, November 14. http://www.windpowermonthly.com/article/1221030/facebook-signsdeal-midamerican-wind-energy.

State of Alabama Public Service Commission 2015a. "Petition: For a certificate of convenience and necessity for the construction or acquisition of renewable energy and environmentally specialized generating resources and the acquisition of rights and the assumption of payment obligations under power purchase arrangements pertaining to renewable energy and environmentally specialized generating resources, together with all transmission facilities, fuel supply and transportation arrangements, appliances, appurtenances, equipment, acquisitions and commitments necessary for or incident thereto." https://www.pscpublicaccess.alabama.gov/pscpublicaccess/ViewFile.aspx?Id=e014291c-4450$\underline{4 \mathrm{f} 3 \mathrm{e}-\mathrm{bb} 28-47 \mathrm{e} 2 \mathrm{e} 1 \mathrm{ca} 1021}$.

State of Alabama Public Service Commission 2015b. "In re: For Evaluation and Approval of the Anniston Army Depot Solar Project and the Fort Rucker Solar Project." https://www.pscpublicaccess.alabama.gov/pscpublicaccess/ViewFile.aspx?Id=bd1dd4a8-dcc14e83-a3df-4d4642416053.

State of Alabama Public Service Commission. 2016. "Petition: For Evaluation and Approval of the LaFayette Solar Project." 
https://www.pscpublicaccess.alabama.gov/pscpublicaccess/ViewFile.aspx?Id=00198ee2-deae44e0-b326-c9bf3f77b01b.

Tawney, Letha, Priya Barua, Celina Bonugli, and Bryn Baker. 2017. Emerging Green Tariffs in U.S. Regulated Electricity Markets (Technical Report). Washington, D.C.: World Resources Institute. http://www.wri.org/sites/default/files/Emerging_Green_Tariffs_in_US_Reg_Elec_Markets_May 2017 0.pdf.

Taylor, Mike, Joyce McLaren, Karlynn Cory, Ted Davidovich, John Sterling, and Miriam Makhyoun. 2015. Value of Solar: Program Design and Implementation Considerations (Technical Report NREL/TP-6A20-62361). Golden, CO: National Renewable Energy Laboratory. http://www.nrel.gov/docs/fy15osti/62361.pdf.

Thomas, J. 2007. "Wal-Mart Creates Its Own Electricity Company, Eyes Wind Power." Treehugger, January 29. https://www.treehugger.com/renewable-energy/wal-mart-creates-itsown-electricity-company-eyes-wind-power.html.

U.S. Energy Information Administration. 2016. "Electricity: Electric Power Sales, Revenue, and Energy Efficiency Form EIA-861 Detailed Data Files.” Last modified November 21, 2016. https://www.eia.gov/electricity/data/eia861/.

University of California. 2016. "UC to Purchase Solar Energy, Partner with Frontier Renewables." https://www.universityofcalifornia.edu/press-room/uc-make-large-purchase-solarenergy-partner-frontier-renewables.

Ward, Getahn. 2015. "Google to Invest in New Clarksville Data Center." The Tennessean, December 21. http://www.tennessean.com/story/money/real-estate/2015/12/21/google-invest500m-new-clarksville-data-center/77474046/.

Whaley, Sean. 2016a. “MGM Resorts to Leave Nevada Power, Pay \$86.9M Exit Fee.” Las Vegas Review-Journal, May 19. https://www.reviewjournal.com/business/energy/mgm-resortsto-leave-nevada-power-pay-86-9m-exit-fee/.

Whaley, Sean. 2016b. "Caesars Applies to PUC to Withdraw as NV Energy Retail Customer and Ply Open Market.” Las Vegas Review-Journal, November 30.

https://www.reviewjournal.com/local/local-nevada/caesars-applies-to-puc-to-withdraw-as-nvenergy-retail-customer-and-ply-open-market/.

World Resources Institute. 2017. "Grid Transformation: Green Tariff Deals." Last modified April 2017. http://www.wri.org/resources/charts-graphs/grid-transformation-green-tariff-deals. 